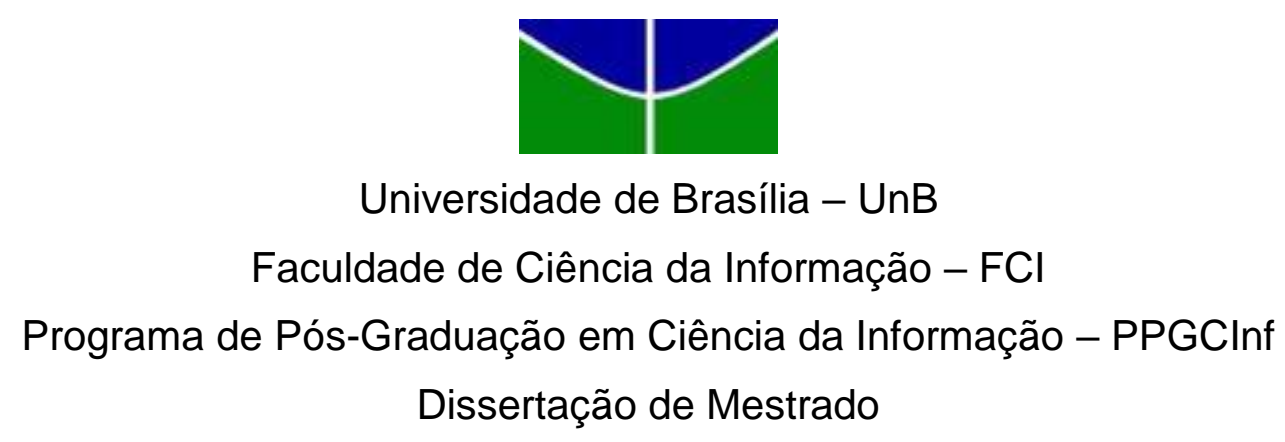

Tânia Maria de Moura Pereira

ANÁLISE DO FLUXO DE DOCUMENTOS FOTOGRÁFICOS DE ARQUIVO: Estudo de Caso da Secretaria de Comunicação da Universidade de Brasília

Brasília-DF 


\section{ANÁLISE DO FLUXO DE DOCUMENTOS FOTOGRÁFICOS DE ARQUIVO: Estudo de Caso da Secretaria de Comunicação da Universidade de Brasília}

Trabalho de Conclusão de Curso apresentado ao Programa de Pós-Graduação em Ciência da Informação, Faculdade de Ciência da Informação da Universidade de Brasília, como parte dos requisitos para obtenção do título de Mestre em Ciência da Informação.

Linha de pesquisa: Organização da Informação.

Grupo de pesquisa: Acervos Fotográficos.

Orientador: Prof. Dr. André Porto Ancona Lopez. 
Ficha catalográfica elaborada automaticamente, com os dados fornecidos pelo(a) autor(a)

PEREIRA, Tânia Maria de Moura

ANÁIISE DO FLUXO DE DOCUMENTOS FOTOGRÁFICOS DE ARQUIVO: Estudo de Caso da Secretaria de Comunicação da Universidade de Brasilia / Tânia Maria de Moura PEREIRA; orientador André Porto Ancona LOPEZ. -Brasilia, .

p.

Dissertação (Mestrado - Mestrado em Ciência dà Informação) -- Universidade de Brasília, .

1. Documento fotográfico de arquivo. 2. Fluxo documental. 3. Gestão da informação. . 4. Secretaria de Comunicação da Universidade de Brasília.. 5. Avaliação de documentos. I. LOREZ, André Porto Ancona, orient. II. Título. 


\section{FOLHA DE APROVAÇÃO}

Título: "Análise do fluxo de documentos fotográficos de arquivo: estudo de caso da Secretaria de Comunicação (SECOM) da Universidade de Brasília (UnB)".

\section{Autor (a): Tania Maria de Moura Pereira}

Área de concentração: Gestão da Informação

Linha de pesquisa: Organização da Informação

Dissertação submetida à Comissão Examinadora designada pelo Colegiado do Programa de Pósgraduação em Ciência da Informação da Faculdade em Ciência da Informação da Universidade de Brasília como requisito parcial para obtenção do título de Mestre em Ciência da Informação.

Brasília, 10 de março de 2016

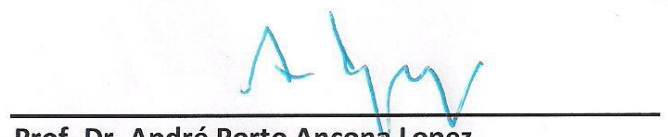

Prof. Dr. André Porto Ancona Lopez

Presidente (UnB/PPGCINF)

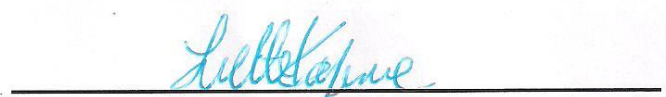

Profa. Dra. Ivette Kafure Muñoz

Membro Titular (UnB/PPGCINF)

\section{Tehansllaos}

Profa. Dra. Telma Campanha de Carvalho

Membro Externo (UNESP)

Prof. Dr. Luiz Carlos Flôres de Assumpção

Membro Suplente 
Escrever é exercer a imaginação criativa como num artesanato em que são ferramentas indispensáveis o dicionário e a gramática. Mesmo para negar ou subverter regras é indispensável conhecê-las. Não se exerce a indômita imaginação senão conjugada ao mais vasto domínio da língua. E, como tais coisas são incomensuráveis, o escrever necessita sempre recomeçar. É sempre um reescrever

Mário Osório Marques 


\section{RESUMO}

O presente estudo teve por objetivo investigar e analisar as relações existentes entre - fluxo de produção de documentos fotográficos de arquivo e a gestão da informação no âmbito da Secretaria de Comunicação da Universidade de Brasília. Para tanto, questionou-se sobre o fluxo de produção de documentos fotográficos de arquivo de uma assessoria de comunicação organizacional e como ele se relaciona com a gestão da informação. De modo específico, fez-se importante caracterizar as atribuições da referida Secretaria, mapear o contexto de produção dos documentos fotográficos de arquivo, apresentar uma proposta de ficha diplomática do documento fotográfico e relacionar as informações obtidas com as etapas da gestão da informação. A estratégia metodológica escolhida foi o estudo de caso da assessoria de comunicação institucional de uma instituição pública de ensino superior, sendo conduzido pela busca de ampliação das discussões em torno dos acervos fotográficos na perspectiva orgânica, sobretudo, acerca do fenômeno do documento fotográfico digital. Inserido no campo teórico da Ciência da Informação e apoiado em disciplinas como, por exemplo, a Diplomática Documental, o estudo aspirou contribuir nos níveis epistemológico, científico e prático referentes à organização documental, com foco na comprovação de atividades administrativas e descrição, acesso e recuperação de informações. Entre os resultados obtidos tem-se a identificação da missão institucional da Secretaria de Comunicação da Universidade de Brasília e suas atribuições, a elaboração de gráfico representativo do fluxo do documento fotográfico produzido por aquela Secretaria, a elaboração de um modelo instrumental de ficha diplomática contendo os elementos intrínsecos e extrínsecos característicos do documento fotográfico, e a articulação entre as etapas da gestão da informação (criação, seleção, utilização e divulgação) com o fluxo de produção dos documentos fotográficos de arquivo num contexto específico. Concluiu-se que a formação do arquivo fotográfico no contexto do caso estudado se deu a partir de uma demanda vinculada entre a missão institucional e as atribuições e os objetivos da Secretaria de Comunicação. Assim, a compreensão da utilização do documento fotográfico, respeitada sua condição de documento de arquivo, acumulado em decorrência de funções e atividades de seu produtor, exigem intervenções metodológicas que possibilitem a definição de uma política de avaliação dos documentos fotográficos acumulados pela instituição.

Palavras-chave: Documento fotográfico de arquivo. Fluxo documental. Gestão da informação. Secretaria de Comunicação da Universidade de Brasília. 


\begin{abstract}
This study aimed to investigate and analyze the relationship between the file photographic document production flow and management of information within the Secretaria de Comunicação at the Universidade de Brasilia. Therefore, if questioned about the file photographic document production flow of an organizational communication advice and how it relates to the management of information specifically, it became important to characterize the duties of said Secretariat, map the context of production of archival photographic documents, submit a proposal for the diplomatic record of the photographic document and relate the information obtained through the steps of information management. The chosen methodological strategy was the case study of institutional press office of a public institution of higher education, being driven by the search for expansion of discussions about the photographic collections in the organic perspective, especially about digital photographic document phenomenon. Inserted in the Information Science field of information and supported in disciplines such as, for example, the Diplomatic Document, the study aspired to contribute in epistemological levels, scientific and practical concerning the documentary organization, focusing on evidence of administrative activities and description, access and retrieval information. Among the results is the identification of the Secretariat of the institutional mission of Secretaria de Comunicação at the Universidade de Brasilia and its tasks, the production of representative graph of the photographic document flow produced by this Secretariat, the development of an instrumental model of diplomatic form containing the intrinsic and extrinsic elements characteristic of the photographic document and the relationship between the stages of information management (creation, selection, use and disclosure) with the production flow of the photographic archive documents in a specific context. It was concluded that the formation of the photographic archive in the context of the case study occurred from a linked demand between institutional mission and the tasks and objectives of the Communications Secretariat. Thus, understanding the use of the photographic document, respected its archive document condition, accumulated as a result of its producer functions and activities, require methodological assistance to enable the definition of an evaluation policy of photographic documents accumulated by the institution.
\end{abstract}

Keywords: Archival photographic document. Document flow. Management of information. Secretaria de Comunicação at the Universidade de Brasília 


\section{LISTA DE FIGURAS}

Figura 1 - Possibilidades de produção de fotografias na Secretaria de Comunicação da Universidade de Brasília..................................... 49

Figura 2 - Fluxo de produção dos documentos fotográficos na Secretaria de Comunicação da Universidade de Brasília....................................... 57

Figura 3 - Ficha diplomática do documento fotográfico.................................. 61 


\section{LISTA DE QUADROS}

Quadro 1 - Detalhamento dos objetivos específicos e estratégias utilizados

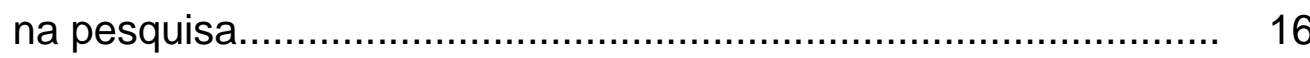

Quadro 2 - Missão e objetivos da Secretaria de Comunicação da Universidade de Brasília.......................................................... 48

Quadro 3 - Meios e canais de comunicação na Universidade de Brasília....... 50

Quadro 4 - Elementos BMP utilizados no fluxograma.................................... 55

Quadro 5 - Argumentação comparativa entre os objetivos propostos e os resultados obtidos......................................................................... 72 


\section{LISTA DE ABREVIATURAS E SIGLAS}

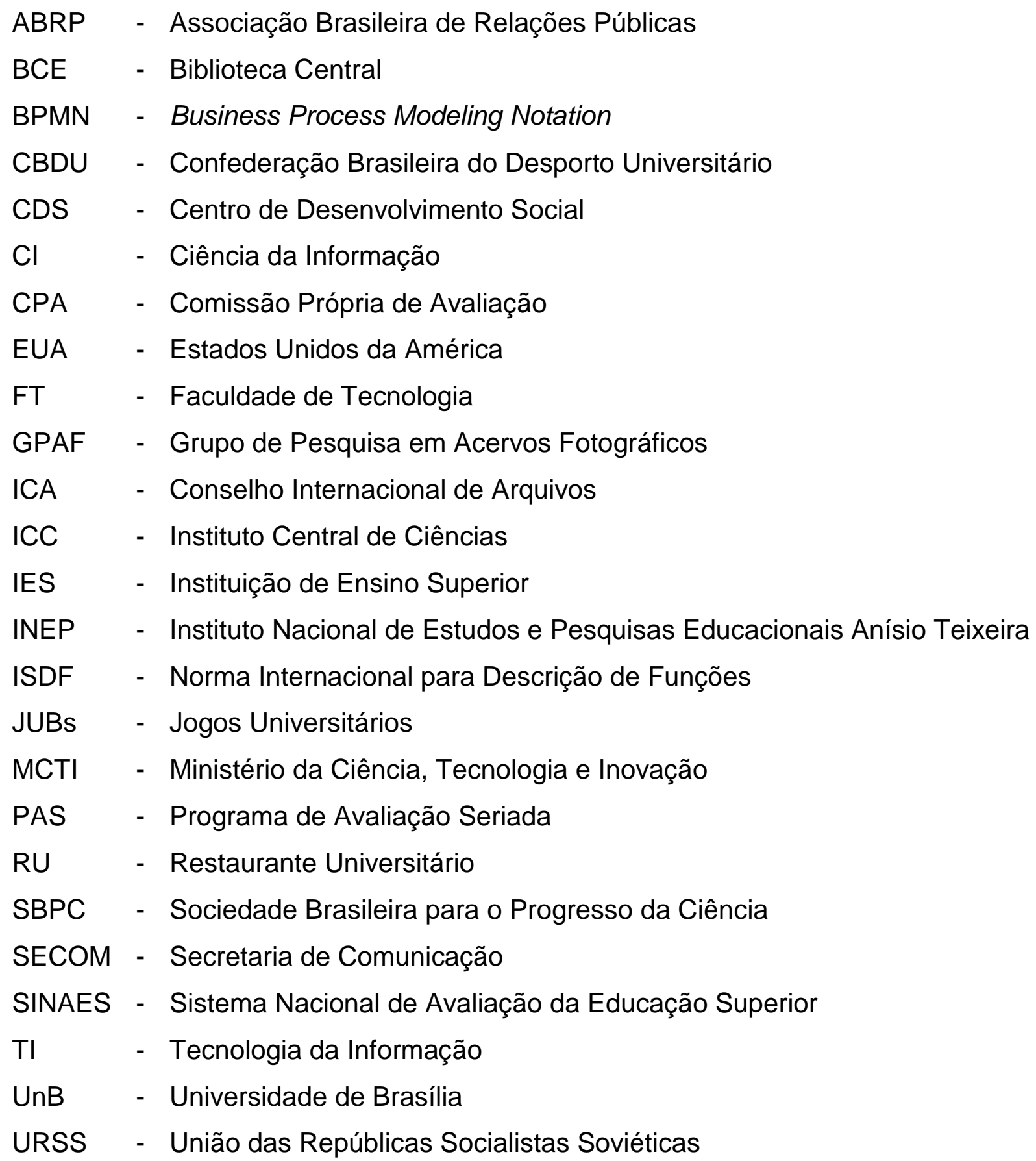


1 INTRODUÇÃO

1.1 ProBlema

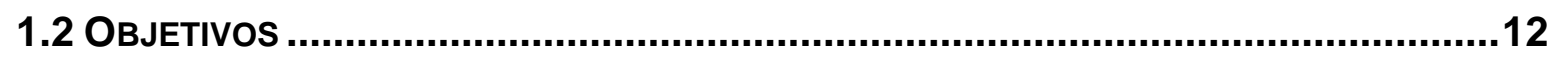

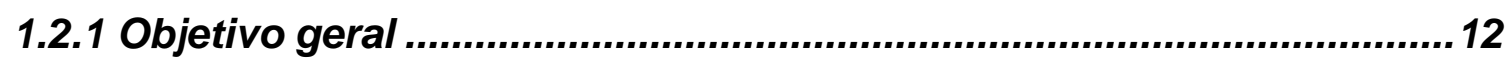

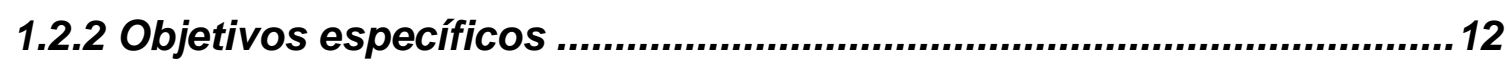

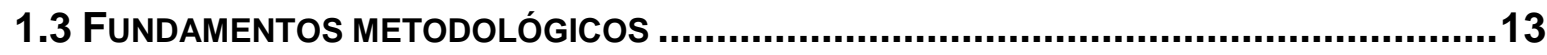

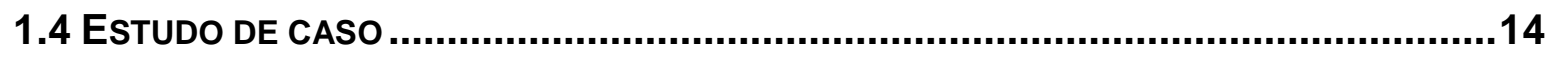

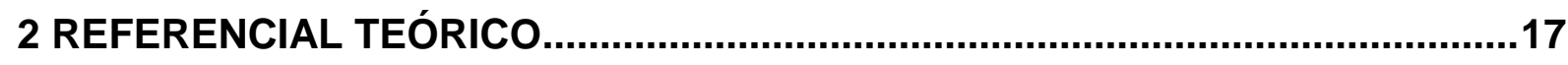

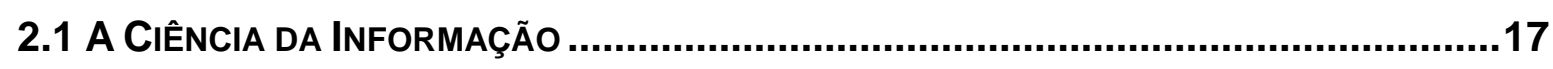

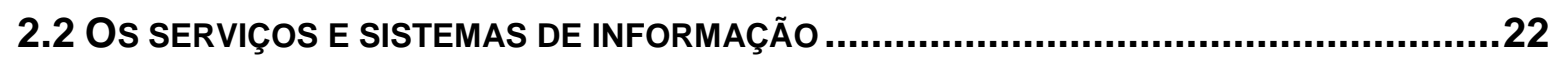

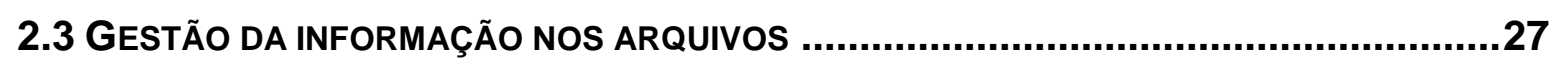

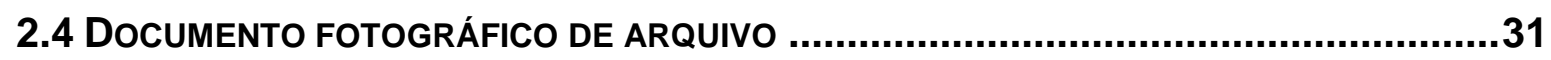

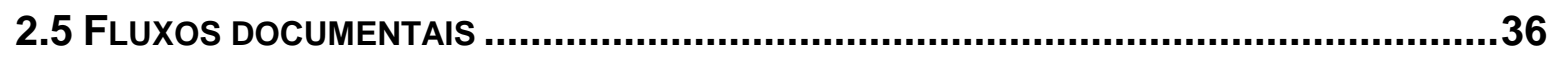

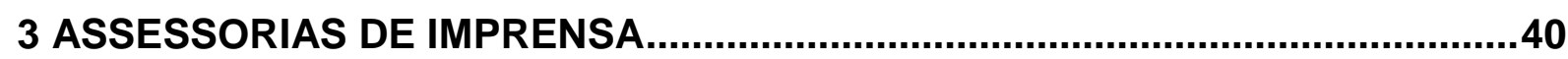

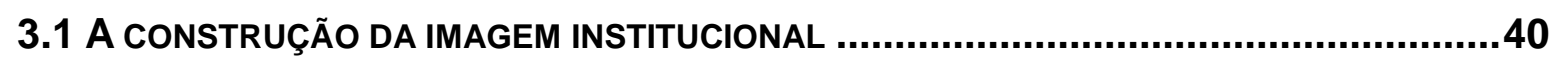

3.2 A SeCretaRia de Comunicação da UniverSidade de Brasília ..........................44

4 MAPEAMENTO DO FLUXO DE PRODUÇÃO DOS DOCUMENTOS...................54

5 FICHA DIPLOMÁTICA DO DOCUMENTO FOTOGRÁFICO ............................61

6 A GESTÃO DA INFORMAÇÃO E OS DOCUMENTOS FOTOGRÁFICOS............65

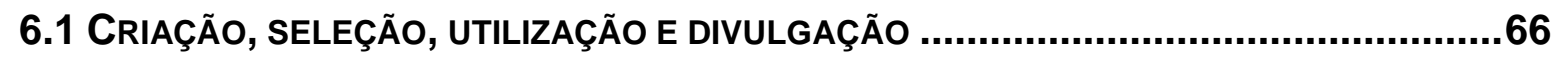

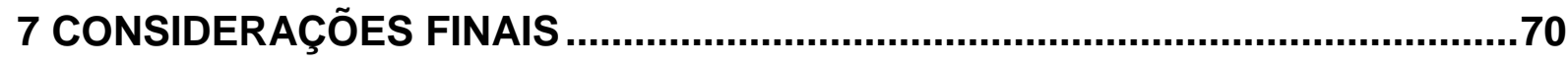

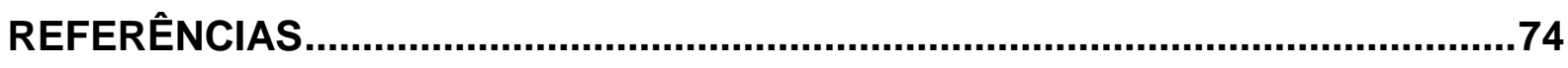

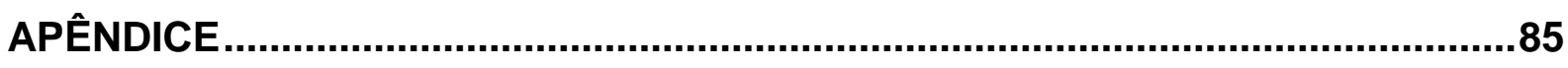

APÊNDICE "A" - RESUMO DA ENTREVISTA COM O FOTÓGRAFO DA

SECRETARIA DE COMUNICAÇÃO DA UNIVERSIDADE DE BRASÍLIA ...............86 


\section{INTRODUÇÃO}

O desenvolvimento da Arquivologia enquanto disciplina considera as relações dos documentos entre si e dispõe do princípio da proveniência como norteador das ações sobre os conjuntos documentais produzidos, acumulados e utilizados como fonte de prova e informação por entidades, públicas ou privadas, pessoas ou famílias. O princípio é definido por Rousseau e Couture (1988, p. 91) como o "conjunto de documentos de qualquer natureza reunidos automática e organicamente, criados e/ou acumulados e utilizados por uma pessoa física ou moral ou por uma família no exercício das suas actividades ou das suas funções".

Entretanto, em alguns casos, é possível observar o desprezo de tal princípio, uma vez que se faz uso de critérios originados nas bibliotecas, coerentes com a tradição de ali se depositarem as obras e os demais papéis dos escritórios. Neste sentido, os documentos são tratados um a um, acarretando em unidades descritivas autônomas, sem levar em conta o contexto em que foi produzido (CAMARGO; GOULART, 2007). A prática é bastante usual nas instituições.

Não obstante serem tentativas bem-intencionadas de preservação do suporte ou da informação registrada em tais documentos, as intervenções fundamentadas em metodologias emprestadas de áreas como, por exemplo, a Biblioteconomia e a Análise Documentária, podem comprometer o caráter probatório dos documentos de arquivo, pois desconsideram-se os motivos para os quais aqueles documentos foram produzidos pela instituição ou pessoa.

A situação fica mais delicada quando se trata de documentos não textuais, como as fotografias, por exemplo. Estas, na condição de arquivo, faz com que seja indispensável a manutenção dos vínculos com as razões que lhes deram origem, sob pena de perda da qualidade de documentos orgânicos. Assim, quando da identificação dos conteúdos das imagens para fins de classificação e organização dos arquivos, compromete-se a recuperação das informações de prova, intimamente ligadas ao contexto de proveniência. Tem-se ainda outro aspecto destacado por Lopez (2008, p. 14), qual seja: 
En el documento fotográfico, la cuestión del origen se vuelve aparentemente más complicada, debido a una incidencia mayor de reciclaje de información. O sea, la aparición de la misma imagen en documentos diferentes es más frecuente que en el caso de documentos textuales. Los avances técnicos en el modo de producción de los documentos textuales siempre tuvieron una estrecha relación con los procedimientos administrativos siendo, por lo tanto, fácilmente incorporados a la realidad de la organización de documentos. De este modo, técnicas de duplicación de texto - tales como papeles especiales, pantógrafos, máquinas duplicadoras (fotocopiadoras, por ejemplo), etc. - fueron rápidamente asimilados por los documentalistas, pero también desencadenaron discusiones sobre el estatuto documental del original y de las copias. Hoy en día, en el caso del texto, existe un consenso al respecto de que los medios tecnológicos reproducen la información y no el documento, sin embargo, cuando se pasa del análisis de un documento textual al de un registro fotográfico, la distinción entre información y documento no queda tan clara.

O uso massivo das tecnologias digitais torna a situação ainda mais complexa, pois, a rapidez que faz surgirem novos equipamentos e aplicativos é a mesma que os torna obsoletos, dificultando a gestão dos documentos e informações ali geradas ambientes que, inevitavelmente, se efetivam na internet. Em relação aos documentos fotográficos:

[...] é preciso acompanhar também a evolução tecnológica que inclui, entre os suportes fotográficos tradicionais, também os documentos fotográficos digitais e eletrônicos. Diante disso fica evidente a importância de uma descrição confiável e um conjunto padronizado de elementos para o intercâmbio de informações entre instituições na Internet (PAVEZI; FLORES; PEREZ, 2009, p. 200).

Diante do exposto, a importância da presente pesquisa para a Ciência da Informação $(\mathrm{Cl})$ e, sobretudo, para a Arquivologia, advém da necessidade de investigar, de modo sistemático, a natureza complexa da informação orgânica. De fato, além de prospectar e monitorar processos e contextos de instituições produtoras de tais informações, o "planejamento, controle e utilização da informação é uma atividade importante, decisiva para o sucesso ou fracasso do organismo" (ROUSSEAU; COUTURE, 1998 p. 65), tendo em vista que a evolução das estratégias administrativas, impulsionada pelas inovações tecnológicas, exerce forte influência no comportamento organizacional dos criadores de registros e suas culturas de trabalho.

Tem-se a necessidade de entender as relações existentes entre a gestão da informação produzida no contexto de uma assessoria de comunicação e o fluxo de produção de documentos fotográficos que buscam fundamentar novos 
conhecimentos. O apoio de disciplinas, como, por exemplo, o Mapeamento de Processos e da Diplomática, serão essenciais para complementar o caminho a ser trilhado em direção à fração de realidade observada. A busca de respostas possíveis deve ser permeada de transparência, para que possa adquirir estatuto de cientificidade, o que proporcionará que outros pesquisadores possam seguir o caminho trilhado e ampliá-lo.

\subsection{Problema}

Qual o fluxo de produção de documentos fotográficos de arquivo de uma assessoria de comunicação organizacional? Como tal fluxo de produção de documentos fotográficos de arquivo se relaciona com a gestão da informação?

\subsection{Objetivos}

\subsubsection{Objetivo geral}

Analisar as relações entre os fluxos formais de registro da informação na produção de documentos fotográficos de arquivo de uma assessoria de comunicação organizacional e a gestão da informação.

\subsubsection{Objetivos específicos}

a) Caracterizar a Secretaria de Comunicação da Universidade de Brasília (SECOM/UnB);

b) Mapear o contexto de produção dos documentos fotográficos de arquivo na SECOM/UnB;

c) Estruturar a ficha diplomática do documento fotográfico; e

d) Traçar as linhas de relacionamento da gestão da informação com o fluxo de produção de documentos fotográficos de arquivo. 


\subsection{Fundamentos metodológicos}

Para a condução de uma pesquisa, a escolha da metodologia não se limita a um conjunto de regras fixas - apesar da repetição de procedimentos necessários -, mas a um conjunto de técnicas aplicadas sequencialmente na cronologia de uma pesquisa, em conformidade com o que indica Tomanik (2004, p. 35):

[...] cada tipo de pesquisa, cada objeto, cada assunto, cada problema de pesquisa, cada população ou situação a ser pesquisada deve merecer, por parte do cientista, um elaborado raciocínio sobre qual seria o método, ou os métodos mais adequados para este problema, esta teoria, esta população e até para este momento histórico.

Por tratar-se de uma pesquisa exploratória, Silva (2005) aponta que o modus operandi exploratório proporciona maior familiaridade com o problema, visando torná-lo explícito sem, no entanto, se propor a construir hipóteses relacionadas às possibilidades de fixar normas e padrões de sistematização da informação. O planejamento da pesquisa buscou detalhar cada etapa a partir do objetivo específico que a conduz, o que possibilitou a escolha dos instrumentos de coleta mais adequados, tendo em vista que a metodologia deve, segundo Bruyne et al. (1977, p. 29), "ajudar a explicar não apenas os produtos da investigação científica, mas principalmente seu próprio processo, pois suas exigências não são de submissão estrita a procedimentos rígidos, mas antes de fecundidade na produção dos resultados".

Neste aspecto, a fundamentação da escolha do caminho crítico está inserida no campo teórico da $\mathrm{Cl}$, de modo que o intuito aqui empreendido foi traçar um plano metodológico necessário ao atingimento dos objetivos delimitados, os quais determinam um tipo de método a ser empregado em cada etapa. Assim, conforme Rampazzo (2004, p. 33), "o método se concretiza nas diversas etapas ou passos que devem ser dados para solucionar um problema", tendo como fio condutor um questionamento e a finalidade de problematização do fenômeno observado. 


\subsection{Estudo de caso}

Para a realização da presente pesquisa, optou-se pelo estudo de caso na perspectiva de reunir a maior quantidade de informações e detalhes possíveis de uma situação, com base na compreensão do fenômeno da produção de documentos fotográficos digitais, a fim de explicar as relações de pertinência e implicação com os conceitos e limites teóricos.

Comumente se faz uso do modo de investigação do estudo de caso para "reconhecer nele um padrão científico já delineado, no qual possa ser enquadrado" (SANTOS, 2007, p. 33). Portanto, no estudo de caso, procura-se reconhecer uma característica possível de generalização, de modo a ultrapassar a particularização. Não obstante tal generalização dependa da influência e validade transitória das informações, pretende-se esmiuçar os aspectos característicos e as complexidades dos fatos e fenômenos que redundaram na situação atual do caso examinado.

Bruyne et al. (1977) classificam os estudos de caso em 03 (três) grupos, a saber: 1) aqueles que intentam fazer uma exploração para descobrir problemáticas novas; 2) aqueles que se propõem a renovar as perspectivas existentes ou sugerir hipóteses para estudos futuros; e, 3) aqueles que se limitam a descrever toda a complexidade do caso sem pretender obter o geral. Aqueles autores também apontam a existência do grupo que persegue objetivos práticos e utilitários. Este último tipo de estudo de caso concentra-se em problemas concretos e particulares decorrentes do funcionamento de uma organização e são eivados de pragmatismo, além de visarem a prescrição de soluções de mudança nas organizações estudadas. Por outro lado, Yin (2001, p. 19) afirma que a utilização do estudo de caso como ferramenta de pesquisa pode contribuir para a compreensão dos fenômenos, sejam eles individuais, organizacionais, sociais e políticos, indicando que, em geral, os estudos de caso representam a estratégia preferida quando se colocam questões do tipo "como" e "por que", quando o pesquisador tem pouco controle sobre os eventos e quando o foco se encontra em fenômenos contemporâneos inseridos em algum contexto da vida real.

Embora a interpretação dos dados extraídos dos estudos de caso possua um caráter particularizante, seu poder de generalização é circunstancial, e a validade é limitada às informações obtidas. Neste sentido, o estudo de caso executado em determinado quadro teórico impõe a definição precisa dos níveis de análise, 
pressupõe a separação entre 0 acidental e o essencial e exige do pesquisador parcimônia nas generalizações. Assim, a presente pesquisa foi desenvolvida conforme segue:

I. O primeiro objetivo específico - caracterizar a SECOM/UnB - se deu em 02 (duas) etapas, a saber: 1) conceituar as competências específicas; e, 2) descrever as ações que ela executa para o cumprimento de suas atribuições. Em tais etapas foram obtidas informações extraídas de pesquisa documental e bibliográfica.

II. O segundo objetivo específico - mapear o contexto de produção dos documentos fotográficos de arquivo na SECOM/UnB - se deu por meio de coleta in loco de informações e elaboração de esquema gráfico do fluxo de produção (fluxograma) das fotografias. Para a coleta de informações fez-se uso do recurso da entrevista formal não estruturada, e para o fluxograma, um software de desenho de processos de trabalho.

III. O terceiro objetivo específico - estruturar a ficha diplomática do documento fotográfico - se deu por um modelo de ficha descritiva adequada ao objeto, com base nos estudos de Duranti (1995), Lopez (1999), Bellotto (2002) e Rezende e Lopez (2014).

IV. Quanto ao quarto objetivo específico - traçar as linhas de relacionamento da gestão da informação com o fluxo de produção de documentos fotográficos de arquivo -, este se deu via registro argumentativo, a partir da comparação entre as etapas da gestão da informação e as práticas utilizadas no ambiente corporativo analisado. 
Quadro 1 - Detalhamento dos objetivos específicos e estratégias utilizados na pesquisa.

\begin{tabular}{|l|l|l|}
\hline \multicolumn{1}{|c|}{ Objetivo Específico } & \multicolumn{1}{|c|}{ Estratégia(s) } & \multicolumn{1}{|c|}{ Recurso(s) } \\
\hline I. Caracterizar a SECOM/UnB. & $\begin{array}{l}\text { Conceituar as competências } \\
\text { específicas; } \\
\text { Descrever as ações executadas } \\
\text { para o cumprimento das } \\
\text { atribuições. }\end{array}$ & $\begin{array}{l}\text { Pesquisa documental e } \\
\text { bibliográfica. }\end{array}$ \\
\hline $\begin{array}{l}\text { II. Mapear o contexto de } \\
\text { produção dos documentos } \\
\text { fotográficos de arquivo na } \\
\text { SECOM/UnB. }\end{array}$ & $\begin{array}{l}\text { Coletar informações in loco; } \\
\text { Elaborar esquema gráfico do } \\
\text { fluxo de produção (fluxograma) } \\
\text { representando os usos das } \\
\text { fotografias. }\end{array}$ & $\begin{array}{l}\text { Entrevista formal não } \\
\text { estruturada e software desenho } \\
\text { de processos de trabalho. }\end{array}$ \\
\hline $\begin{array}{l}\text { III. Estruturar a ficha } \\
\text { diplomática do documento } \\
\text { fotográfico. }\end{array}$ & $\begin{array}{l}\text { Elaborar modelo de ficha } \\
\text { descritiva adequada ao objeto } \\
\text { documento fotográfico. }\end{array}$ & $\begin{array}{l}\text { Pesquisa bibliográfica e } \\
\text { documento fotográfico de } \\
\text { arquivo. }\end{array}$ \\
\hline $\begin{array}{l}\text { IV. Traçar as linhas de } \\
\text { relacionamento da gestão da } \\
\text { informação com o fluxo de } \\
\text { produção de documentos } \\
\text { fotográficos de arquivo na } \\
\text { SECOM/UnB. }\end{array}$ & $\begin{array}{l}\text { Comparar as etapas da gestão } \\
\text { da informação com as práticas } \\
\text { realizadas na SECOM/UnB. }\end{array}$ & $\begin{array}{l}\text { Informações obtidas a partir do } \\
\text { caso e pesquisa bibliográfica. }\end{array}$ \\
\hline
\end{tabular}

Fonte: Dos autores.

A estratégia de pesquisa é fundamentada e conduzida pela forma como o problema foi elaborado e busca responder a questionamentos de "como" e "por que" relacionados ao fenômeno do documento fotográfico digital. Conquanto não haja exigência de controle sobre eventos comportamentais, o tipo de pesquisa aqui empreendido teve como foco os acontecimentos contemporâneos - analisados em contraponto às reflexões fundamentadas nas teorias estudadas. 


\section{REFERENCIAL TEÓRICO}

\subsection{A Ciência da Informação}

O termo "Ciência da Informação" foi utilizado pela primeira vez em 1955 pelo inglês Jason E. L. Farradane, porém, sem uma definição clara, o que somente se deu entre 1961 e 1962 nas reuniões do Georgia Institute of Technology, nos Estados Unidos da América (EUA). Destas participavam profissionais de vários campos, a saber: bibliotecários, engenheiros, físicos, matemáticos, analistas de sistemas, químicos, médicos, estatísticos, administradores, economistas, farmacêuticos, filósofos, historiadores, linguistas, meteorologistas, geógrafos, entre outros. Mesmo tendo iniciado seus primeiros movimentos no século XVII, não há um consenso sobre seu conceito ou objeto de estudo.

Diante do exposto, as linhas que se seguem traçam os contornos históricos e conceituais da Ciência da Informação (Cl) e seu objeto de estudo: a informação enquanto fenômeno social.

Para Pinheiro (2005), a Cl se constituiu como uma maneira de romper com um passado de práticas que não se mostravam mais competentes para atender as necessidades bibliográficas e documentais de uma sociedade marcada pela explosão tecnológica e, principalmente, de uma comunidade científica em contínuo processo de crescimento.

Envolvida com o propósito de investigar o comportamento e as propriedades da informação, a $\mathrm{Cl}$ vem se consolidando por meio da relação com diferentes áreas do conhecimento, entre elas, a Biblioteconomia, a Documentação, a Comunicação, a Tecnologia da Informação (TI) e algumas outras. Tais áreas têm em comum o objeto de estudo: a informação - considerada de suma relevância para a sociedade, tanto no âmbito social como organizacional, e influencia desde as atividades do cotidiano do indivíduo até a tomada de decisão nas organizações, conforme explica Almeida (2007):

A informação que realmente importa é a utilizável para tomar conhecimento de algo, elucidar decisão em uma dada situação, formar a consciência do cidadão, promover o crescimento intelectual, enfim, sempre deve ser processada para um propósito, uma meta definida. A principal característica desse modo de apresentar a realidade é a procura de fins últimos. Naturaliza-se a ideia de que a informação é a mola propulsora que contribui 
para o desenvolvimento econômico, que liberta e que promove o bem das pessoas, indiscutivelmente. Nos espaços de trabalho, a informação tem seu lugar como entidade que determina o nível de relacionamento das pessoas, quanto mais informação circula mais interação existe entre os sujeitos.

O desenvolvimento de uma pretensa ciência interessada na análise sistemática do fenômeno da informação se consolida a partir de meados do século $X X$, com base na crescente atenção dispensada pela comunidade científica e governos nas questões relacionadas à informação. Iniciam-se esforços no sentido de definir e delimitar a nova disciplina que, para Fonseca (2005), podem ser agrupados em 03 (três) vertentes, quais sejam: 1) reconhecer a polissemia do termo informação e as diferentes características do fenômeno informacional; 2) reconhecer e exercer a interdisciplinaridade da área; e, 3) perceber a real participação das Tls e repudiar a interpretação de $\mathrm{Cl}$ como sinônimo de informática.

A multiplicidade de significados do termo "informação" continua sendo um grande desafio para a delimitação do campo de estudo da $\mathrm{Cl}$, pois, a complexidade do fenômeno informacional depende da carga semântica que the é atribuída e também do contexto no qual está inserido. Como exemplo da referida pluralidade de sentidos é a análise dos atributos proporcionados por pequena amostra de definições do termo outrora apresentado realizado por McGarry (1984, p. 17), que aponta como principais argumentos:

A informação pode ser considerada quase sinônimo de fato. Tem por efeito
transformar ou reforçar o que é conhecido ou julgado conhecido, por um ser
humano. A informação é utilizada como coadjuvante da decisão. A
informação é a liberdade de escolha que se tem ao selecionar uma
mensagem. A informação é 'algo' necessário quando enfrentarmos uma
escolha. A quantidade requerida depende da complexidade a decisão a
tomar. A informação é a matéria-prima de que deriva o conhecimento. A
informação é trocada com o mundo exterior e não meramente recebida. A
informação pode ser definida em termos dos seus efeitos no receptor (com
adaptações).

A informação é um recurso referencial, noção ou ideia que se processa na mente humana e tem sua utilidade na resolução de problemas, o que, em termos quantitativos, "seria a medida do valor líquido obtido na reunião dos elementos dos dados [...] definida em termos dos seus efeitos sobre o mapa cognitivo ou mental do indivíduo" (McGARRY, 1984, p. 17), podendo ser apreendida gerando conhecimento. Mesmo incluídos no campo dos estudos da $\mathrm{Cl}$, conceituar conhecimento e informação não é tarefa fácil, por envolver diversas perspectivas de 
análise, domínios e concepções referentes a cada área em que estão inseridos, conforme Brookes (1980), Le Coadic (1996), Wilson (2002) e Zins (2007).

Vários outros autores se esmeraram em refletir e tentar delimitar tais conceitos, mas sem chegar a um consenso. As reflexões de Lima e Álvares (2012, p. 24, 26) indicam que o conhecimento "está relacionado com os aspectos cognitivos que ocorrem na mente humana e envolvem os processos mentais de captação, assimilação, associação e também de construção, desconstrução e reconstrução de conceitos", enquanto a informação é o "elemento que compõe o conhecimento. Pode-se dizer, de maneira simplificada, que a informação é o conhecimento possível de se materializar e de ser materializado em algum suporte".

Neste sentido, é possível entender que o domínio proclamado da $\mathrm{Cl}$ se restringe à constante informação registrada de sistemas de informação formalmente constituídos para comunicação do conhecimento. Para Belkin (1978), Saracevic (1996) e Capurro (2003), a recuperação da informação, a aquisição, a produção, o armazenamento, o tratamento e a organização, seriam atribuições de interesse dos profissionais de informação, e estes seriam oriundos de áreas ligadas à representação do conhecimento e da transferência de informação, entre as quais: Biblioteconomia, Computação, Comunicação, Linguística, Informática, Psicologia, Sociologia e tantas outras.

A tentativa de identificação de espaços comuns de atuação redundou no desenvolvimento de estudos que pudessem levar ao reconhecimento e exercício da interdisciplinaridade da área um "movimento de superação da monodisciplinaridade, que é o que acontece quando uma disciplina atua de forma isolada, operando apenas com seus próprios conceitos, métodos e objetos de estudo" (SILVA; LIMA; ARAÚJO, 2009, p. 35). O propósito é utilizar o conhecimento de diferentes áreas de pesquisa de modo interativo, com vistas à resolução de problemas práticos decorrentes da complexidade das relações da sociedade atual.

Alguns teóricos da Cl, como, por exemplo, Borko (1968), Foskett (1973), Brookes (1980), Saracevic (1995) e Le Coadic (1996), enfatizam seu aspecto interdisciplinar com base na natureza da informação, entendida como fenômeno do conhecimento humano, qualificado e delimitado pelas distintas relações entre as disciplinas. Porém, Japiassú e Marcondes (1991, p. 150) consideram a interdisciplinaridade como método de pesquisa e ensino, conforme o que se segue: 
[...] suscetível de fazer com que duas ou mais disciplinas interajam entre si, esta interação podendo ir da simples comunicação das ideias até a integração mútua dos conceitos, da epistemologia, da terminologia, da metodologia, dos procedimentos, dos dados e da organização da pesquisa.

A interdisciplinaridade percebida como percurso metodológico da $\mathrm{Cl}$ tem influenciado as pesquisas sobre os sistemas, processos e usos de seu objeto e decorre dos diferentes entendimentos do conceito de informação, que permeia todas as áreas de estudo envolvidas e está relacionada a aplicações específicas, como, por exemplo, a informação científica, a biblioteconômica, a artística, a tecnológica, a jornalística, a arquivística etc. Assim, a interdisciplinaridade atua como uma abordagem convergente para a solução dos problemas existentes em cada área, que apesar de estarem divididas como disciplinas, se complementam enquanto conhecimento. Compreender a informação em seus aspectos particulares e usos específicos é o objetivo da $\mathrm{Cl}$; logo, a interação com as diversas disciplinas do conhecimento se evidencia à medida em que as necessidades informacionais se tornam mais complexas.

É importante tratar da relevância do uso das Tls para o desenvolvimento da $\mathrm{Cl}$ "como uma disciplina tem como meta fornecer um corpus teórico sobre informação que propiciará a melhoria de várias instituições e procedimentos dedicados à acumulação e transmissão de conhecimento" (BORKO, 1968, p. 2). Ao aliar a necessidade de organização e representação das informações de modo estruturado, por meio da linguagem e da geração de novos registros capazes de serem difundidos e reutilizados, a $\mathrm{Cl}$ se ampara no uso da TI. Neste sentido, é preciso recordar que uma das acepções da palavra "tecnologia" refere-se à explicação dos termos próprios das artes, ofícios e manufaturas, formando uma linguagem especial das ciências.

Rudiger (2004, p. 25) indica que o advento da Revolução Industrial, a partir do século XVIII, forneceu as bases para a "tecnificação e cientifização das atividades sociais", o que tem se intensificado ao longo dos últimos séculos e que, no período contemporâneo, torna a sociedade gradativamente mecanizada e instrumentalizada a nível global. Simultaneamente ao desenvolvimento progressivo da sociedade, aquele autor argumenta que o conceito de tecnologia vem sendo ampliado, incorporando o sentido de "conjunto formado por equipamentos e estruturas materiais” (RUDIGER, 2011, p. 74), e que, em um processo de reificação, 
atualmente tem-se a noção de conjunto de sistema abrangente - envolvendo as pessoas, as organizações e as máquinas - em uma concepção que designa uma estrutura material flexível dotada de funcionalidade operatória.

Por fim, como síntese das várias tentativas de definição de tecnologia, a definição de Brooks e Bell (1976 apud CASTELLS, 1999, p. 49) parece mais apropriada para as finalidades aqui pretendidas: "o uso dos conhecimentos científicos para especificar as vias de se fazerem as coisas de uma maneira reproduzível". A influência da tecnologia no cotidiano social é representada pela expressão "tecnologia da informação", que inclui o desenvolvimento da informática dos dispositivos de processamentos dados -, aliado às transformações dos meios de comunicação.

Essa influência é tida como marco de uma verdadeira revolução tecnológica, o que para Castells (1999, p. 50) se manifesta por meio das diversas inter-relações existentes entre os campos de aplicação da tecnologia (genética, medicina, engenharia, transporte etc.) que fazem uso de uma "linguagem digital comum na qual a informação é gerada, armazenada, recuperada, processada e transmitida" de modo convergente, possibilitando o aumento do intercâmbio de novos conhecimentos e estimulando as transformações na economia e na cultura.

Embora hoje a discussão pareça desproporcional, naquele momento tratavase de definição de fronteiras de pesquisas e afirmação de identidades profissionais entre os já atuantes bibliotecários - que se ocupam da informação científica - e os emergentes técnicos de informação - interessados no processamento técnico da informação com o uso de computadores, sem considerar seu significado. No entanto, o conflito entre as áreas de interesses não se estabelece e a evolução dos estudos demonstra que as disciplinas coexistem com possibilidades de atuação distintas, conforme previa Foskett (1980, p. 15) (grifo nosso):

\footnotetext{
Uma nova disciplina não surge simplesmente porque velhos praticantes se desempenham melhor em seus empregos, mas porque dinamicamente novas relações aparecem com outros campos. Neste sentido, a atividade de 'armazenagem e recuperação da informação' é uma Biblioteconomia melhor, mas a Informática está se desenvolvendo como uma nova disciplina pelo fato de que, pela primeira vez, as pessoas estão agora estudando o comportamento da própria informação e as propriedades, ou 'morfologia' no dizer de Fairthorne, ou fluxo de informação.
} 
A partir das referidas discussões começam a se definir os contornos acerca da real participação das TIs no âmbito da $\mathrm{Cl}$, ao mesmo tempo em que ela começa a se diferenciar do escopo da informática. A constante tentativa de demarcação de espaços de especialização no território científico possibilitou que ambas atuassem enquanto disciplinas autônomas, mas não impediu o exercício de uma relação de simbiose, de mútua contribuição em termos práticos, em que cada uma atua dentro de sua perspectiva de domínio.

\subsection{Os serviços e sistemas de informação}

O percurso histórico da Cl é marcado pela associação entre teorias e práticas, e que as mudanças ocorridas na realidade social causadas pela valorização da informação levaram a uma "perspectiva menos patrimonial e mais dinâmica no uso da informação" (RIBEIRO; SILVA, 2008, p. 47), o que exigiu dos profissionais envolvidos clareza para transitar entre a necessidade de conservação dos suportes - por um lado - e o processamento da informação por meios automatizados com vistas ao acesso e divulgação - por outro lado.

Entre as consequências da exigência supramencionada vale destacar a renovação dos serviços de informação praticados pelas bibliotecas e a emergência dos sistemas de informação. Embora seja possível reconhecer que as bibliotecas sejam detentoras de uma busca retrospectiva e de alerta constante (FOSKETT, 1980), não se pode menosprezar a importância das bibliotecas para a educação, a cultura e o desenvolvimento das ciências, mas apenas tentar salientar o dilema que se instalou no contexto de novas sistemáticas de classificação, representação e recuperação da informação registrada. Assim, faz-se importante descrever as características dos serviços de informação em comparação com os sistemas de informação surgidos após a Segunda Guerra Mundial.

Ao revisitar o conceito de $\mathrm{Cl}$, Robredo (2003) expõe alguns eventos que balizaram as mudanças na evolução histórica das bibliotecas desde o final do século XIX até os dias atuais, e levaram ao surgimento da $\mathrm{Cl}$. Entre os mais significativos, aquele autor inclui o Movimento da Documentação, que influenciou a renovação dos serviços de informação das bibliotecas. Portanto, tal renovação seria uma resposta à procura dos usuários por informações e documentos com base em temas e outros critérios. Comparativamente, enquanto as bibliotecas anteriores se encarregavam da 
atividade de reunião de documentos feita por um profissional especializado (bibliotecário) com base em seu julgamento de relevância ou em uma política institucional, os documentos (livros, periódicos, teses e demais publicações) eram processados tecnicamente pelos critérios de título e/ou nome do autor, de modo que pudessem ser localizados fisicamente nas seções das bibliotecas, tornadas pontos de acesso à informação publicada. No entanto, um serviço de informação para o atendimento da nova demanda passa a ter uma configuração centrada nos usuários das bibliotecas, e:

[...] pode ser analisado (e geralmente é) como uma reunião de atividades encadeadas a fim de processar a informação, muitas vezes definida (ou indefinida), mas eventualmente passível de se transformar em marcas [...] alguém identifica, reúne e examina as marcas (livros, periódicos, etc.), codifica seu conteúdo numa linguagem de indexação, armazena o conteúdo codificado numa forma recuperável, e as envia ou a um serviço de alerta, ou como resultado de uma busca retrospectiva (FOSKETT, 1980, p. 33).

A delimitação dos serviços de informação no contexto das bibliotecas públicas se deu pela utilização dos métodos da Bibliografia - disciplina que fundamenta uma concepção tradicionalmente típicas das bibliotecas e trata do estudo e classificação, com a finalidade de elaborar listagens, inventários e catálogos de todos os documentos registrados em qualquer suporte e formatação representativos de determinado conhecimento (assunto, local, língua etc.).

A noção de 'serviço' de informação exerce um efeito muito significativo em relação ao cumprimento da função social de transferência da informação e "coloca os serviços de bibliotecas nos fundamentos dos serviços oferecidos aos vários grupos de usuários" (FOSKETT, 1980, p. 32), tornando-os representativos das aplicações das teorias dos idealizadores da Documentação, que estavam preocupados com a qualidade das publicações e com a necessidade de fomentar a colaboração internacional.

Vale destacar os estudos de Paul Otlet, que se materializam na elaboração de sínteses de documentos a partir de novas concepções da classificação científica das fontes, das fichas de indexação dos conteúdos e da compilação de repertórios bibliográficos universais - o que fazia todo sentido para os serviços de informação que se caracterizam pela produção de materiais secundários como índices, bibliografias e resumos, criados com o intuito de facilitar a recuperação das 
informações registradas em suportes tradicionais, em especial, o papel, e disponíveis em grandes volumes.

Tal contexto começou a se modificar por volta da década de 1970, com o surgimento dos microcomputadores pessoais e 0 investimento das grandes indústrias em equipamentos, softwares, pessoas e suprimentos, a fim de agilizar o trabalho administrativo, aumentando a competitividade das empresas, que se tornaram cada vez mais complexas. A complexidade aqui expressa é caracterizada pela utilização das técnicas e instrumentos combinados aos meios de processamento da informação, de modo que os resultados das diversas partes se inter-relacionem com o todo.

Assim, sob a influência da abordagem sistêmica, diferentes áreas do conhecimento passaram a adotar o termo "sistema" para definir "um conjunto de elementos interdependentes ou um todo organizado, ou partes que interagem formando um todo unitário e complexo" (BIO, 1985, p. 18).

As relações entre as atividades internas das organizações e a sua relação com o meio externo adquiriram importância vital, pois, "o desenvolvimento do conhecimento humano, além de exigir contínua especialização, acaba por provocar também a crescente necessidade de gente capaz de relacionar as partes com o todo: 'generalistas' ou 'desenhistas de sistemas', capazes de sintetizar complexidades" (BIO, 1985, p. 17), o que nos ambientes dinâmicos de competitividade define a sobrevivência das organizações - entendidas como um sistema aberto, conforme se segue:

[...] o sistema aberto pode ser compreendido como um conjunto de partes em constante interação (o que ressalta um dos aspectos fundamentais da ideia de sistemas: a interdependência das partes), constituindo um todo orientado para determinados fins e em permanente relação de interdependência com o ambiente externo, ou seja influenciado pelo ambiente externo. Uma das implicações críticas dos conceitos de sistemas na Administração é justamente a concepção da empresa como um sistema aberto, pois tal visão ressalta que 0 ambiente organizacional, para sobreviver, tenha de responder eficazmente às pressões exercidas pelas mudanças contínuas e rápidas do ambiente (Bio, 1985, p. 18).

Quando se associa tal visão à premissa de que na sociedade moderna a informação é considerada um recurso-chave, torna-se "difícil estabelecer uma separação total entre a informação, a tecnologia e os sistemas de informação" (DAVENPORT, 1994, p. 83). Os sistemas de informação seriam subdivisões do 
sistema maior em que se encontram instalados (empresas, bibliotecas, governos etc.) e se utilizam dos computadores para manipular quantidades crescentes de dados, reunindo e compilando volumes de informações que subsidiam o desenvolvimento de pesquisas científicas e a tomada de decisão, e podem ser definidos como:

[...] um conjunto de componentes inter-relacionados que coletam (ou recuperam), processam, armazenam e distribuem informações destinadas a apoiar a tomada de decisões, a coordenação e o controle de uma organização. Além de dar apoio à tomada de decisões, à coordenação e ao controle, esses sistemas também auxiliam os gerentes e trabalhadores a analisar problemas, visualizar assuntos complexos e criar novos produtos (LAUDON; LAUDON, 2009, p. 9).

O lugar físico fica em segundo plano e a informação passa a ser coletada, manipulada e distribuída para atender as necessidades específicas dos usuários. E, quer seja em uma forma mais tradicional ou no mais alto nível tecnológico, um sistema de informação torna-se irrelevante se não proporcionar no momento certo a informação adequada.

Apesar de inicialmente parecerem uma ameaça aos procedimentos e funções das bibliotecas, o advento dos referidos sistemas de informação possibilitou mudanças nos métodos de trabalho, que passariam a coexistir nos serviços de informações de instâncias governamentais e corporativas, formando centros de excelência constituídos por pessoas, procedimentos e equipamentos, que trabalham de forma interdependente, porém, sujeitos a diversos mecanismos de controle, no processamento de dados e empenhados em gerar a informação que auxiliasse na tomada de decisão em nível gerencial. Tal composição seria um exemplo do fenômeno da industrialização da informação apontado por Kobashi, Smit e Tálamo (2001, p. 3), que, ao analisarem o campo científico da Cl, consideram:

[...] a qualificação da informação pela etimologia da palavra, a associa objetivamente ao coletivo. Verifica-se, por essa via, que a sua importância encontra-se relacionada ao fato de a mesma promover modos de organização social que vão além de noções espaciais e territoriais: a agregação dos indivíduos, assim como a segregação entre eles, faz-se pela informação, sua circulação, distribuição e consumo. 
Choo (2006, p. 67) assevera que o aumento do apoio governamental aos estudos de grupos científicos e tecnológicos possibilitou o mapeamento da pesquisa sobre as necessidades e usos da informação em vários aspectos, conforme se segue:

[...] a busca e o processamento da informação são fundamentais em muitos sistemas sociais e atividades humanas, e a análise das necessidades e dos usos da informação vem se tornando um componente cada vez mais importante da pesquisa em várias áreas como a psicologia cognitiva, estudos da comunicação, difusão de inovações, recuperação da informação, sistemas de informação, tomada de decisões e aprendizagem organizacional.

A possibilidade de acumular e manipular dados, de executar funções até então exercidas pelo cérebro humano, e a popularização da informática foram fatores que tiveram grande influência no desenvolvimento dos sistemas de informação. Ainda na década de 1970, surgiram os softwares para as aplicações de datawarehouse (armazenamento de dados), ou seja, um sistema integrado de informações que se alimenta de fontes de dados de múltiplos sistemas e constitui a base de suporte para a análise e tomada de decisões e o datamining (mineração de dados), que busca a produção do conhecimento analisando dados, descobrindo tendências e fraudes.

Considerando que a geração e o acúmulo cada vez maior de informações exigem tratamento específico para efetivação de seu uso nas mais diferentes situações, Choo (2006) procura identificar os pontos de referência e tendências nos resultados das pesquisas elaboradas até então, conforme sua finalidade e conteúdo, disponibilizando um esquema que indica que as orientações dos estudos vão dos sistemas aos usuários da informação. Aquele autor esclarece que na orientação para o usuário, tem-se a informação como uma construção subjetiva, criada dentro da mente humana, e que o valor de tal informação reside no relacionamento que ele (usuário) constrói para si, atribuindo-Ihe significado.

Por outro lado, no caso da pesquisa orientada para sistemas, a abordagem que aqui nos interessa observa o ambiente externo que cerca o indivíduo e como suas preferências e necessidades cognitivas e psicológicas interferem nos padrões de comunicação da informação. Neste sentido, Choo (2006, p. 68) aponta que na análise do esquema apresentado: 
[...] o termo sistemas tem amplo alcance, já que inclui estruturas sociais, práticas e comunidades destinadas a partilhar e disseminar informações; instrumentos, instrumentos, serviços e agências que facilitam o acesso a informação; assim como sistemas computadorizados que permitem que a informação seja procurada e armazenada.

A necessidade de processamento e organização de grandes volumes de informação determina a maneira como as informações são gerenciadas e é dependente da tecnologia disponível (FERAUD, 2004). Para Feraud (2004), a compreensão do conceito de disseminação da informação consolidou a evolução do processamento de dados, agora associado ao termo "tecnologia da informação", e ilustra a ideia de onipresença da informação por meio da expressão "era da ubiquidade", cujas

[...] marcas registradas são os sofisticados sistemas de informação sistemas de informação gerenciais, sistemas de informação executiva e sistemas de suporte à decisão, a possibilidade de customização de aplicações e softwares e o advento da sociedade em rede, dentre outros (FERAUD, 2004, p. 63).

Portanto, contém a descrição das características dos sistemas de informação a perspectiva de que a informação, enquanto fenômeno, exerce papel tão relevante a ponto de ser objeto de estudos científicos interessados no desenvolvimento de instrumentos e serviços capazes de facilitar-Ihe a organização, o compartilhamento e o acesso nos sistemas sociais, os quais incluem os serviços de informação. É nesse cenário que Castells (1999, p. 38-39) apresenta a sociedade informacional, onde a "comunicação mediada por computadores gera uma gama enorme de comunidades virtuais", que atuam nas mais diferentes áreas, gerenciando informações que são difundidas mundialmente.

\subsection{Gestão da informação nos arquivos}

A gestão da informação é 01 (uma) das 03 (três) áreas onde se divide a $\mathrm{Cl}$. Tais divisões, segundo Robredo (2003), foram propostas por Summer et al. (1999) na tentativa de traçar os limites da $\mathrm{Cl}$. As outras 02 (duas) seriam a $\mathrm{TI}$ e a área núcleo da $\mathrm{Cl}$, sendo que estas teriam sido incluídas no escopo da $\mathrm{Cl}$ a partir do reconhecimento da importância da relação da informação com o conhecimento. Fazendo uso de tal relação, Alvarenga Neto (2005, p. 59), ao examinar a gênese da 
gestão dos recursos informacionais a partir dos estudos de Bergeron (1996), concluiu que a gestão da informação é um dos componentes da gestão do conhecimento e que:

[...] devido à importância crescente do processo decisório, da inovação, do gerenciamento de processos e da aquisição e distribuição da informação na sociedade pós-industrial, a gestão de recursos informacionais (GRI) surge como uma estratégia aperfeiçoada para o gerenciamento eficaz da informação e como uma resposta aos problemas informacionais das organizações - obter a informação.

A noção de que a gestão da informação está contida na gestão do conhecimento amplia a discussão para além do foco da presente pesquisa, que pretende apenas explorar as características da gestão da informação e como ela se manifesta nos arquivos. Não obstante os problemas de a gestão da informação ocuparem a área da $\mathrm{Cl}$ há mais de meio século, eles ainda continuam atuais e levaram ao estabelecimento de metodologias de representação da informação.

Em artigo que aborda o desenvolvimento da $\mathrm{Cl}$ enquanto orientação teórica e prática para o fenômeno da relação da informação com o conhecimento, Barreto (2005, p. 71-72) defende que algumas metodologias se assemelham a um tipo de "reformatação do documento, baseado na sua substituição por indicadores do conteúdo todo". Como exemplo de tais indicadores, têm-se as palavras-chave: expressões extraídas dos conteúdos dos documentos, que representam e sintetizam as informações. Utilizadas para facilitar a recuperação em sistemas informatizados ou não de armazenamento de informações, mostram-se úteis também para a difusão dos acervos custodiados por bibliotecas, centros de documentação, museus e arquivos, pois são referenciais lógicos dos documentos físicos.

Entende-se que a gestão e utilização dos conteúdos informacionais estão essencialmente relacionadas ao conceito de documento como "unidade constituída pela informação e seu suporte" (CAMARGO; BELLOTTO, 1996, p. 28) e coincide com os objetivos da recuperação da informação, dos estudos de usuários e das formalizações de linguagens padronizadas. Assim, o exercício da gestão da informação vai ao encontro do entendimento de Buckland (1999), de que a Cl tem suas origens na documentação e utilização de procedimentos automatizados para processar, gerir e utilizar os documentos em diferentes organizações e contextos, ou 
seja, bibliotecas, agências, museus, arquivos, organizações privadas e órgãos de governo.

Neste sentido, a gestão da informação estaria centrada nos processos e exigências relacionadas ao acesso à informação registrada e seria implícita ao conceito de informação que, para McCreadie e Rice (1999 apud ROBREDO, 2003, p. 76), inclui "também os aspectos relativos aos processos informacionais e às influências e exigências que pesam sobre o acesso à informação". Aqueles autores estabeleceram um modelo de acesso à informação que incluía as inter-relações entre os indivíduos, os grupos e as organizações - componentes a serem considerados no atendimento às necessidades de acesso à informação.

As necessidades informacionais são explicitadas em ambientes organizacionais diversificados, os quais utilizam e reconhecem a importância da informação como um recurso estratégico bastante demandado e passível de subsidiar interferências no seu desempenho administrativo. Nos espaços corporativos é evidente que a gestão da informação engloba tanto a informação em si, quanto os aspectos ligados ao planejamento, controle e exploração dos recursos informacionais, entre os quais, aqueles de nível pessoal, finanças, marketing, organização e os sistemas de informação.

Os serviços de informação, por sua vez, se encarregariam de prover, quando solicitados, as informações suficientes para a tomada de decisões esclarecidas, de modo rápido e eficaz. Assim,

[...] sob essa perspectiva, o contexto organizacional no qual se dá o processo de busca e uso da informação passa a ser visto como um conjunto de condições inter-relacionadas, as quais promovem o entendimento compartilhado de significados [...] (BLATTMANN; RODRIGUES, 2011, p. 53).

formando estratégias decisórias.

A convivência de diversificados tipos de acervos em uma mesma instituição é factível, mas demanda tratamentos específicos. Cada vez mais é esperada uma harmonização de esforços no sentido da realização de tratamentos abrangentes das informações sem, contudo, deixar de lado as particularidades de cada conjunto documental. Tal vertente da gestão da informação indica a necessidade de convergência de atuação dos diferentes profissionais envolvidos, pois: 
[...] a organização que os emprega, para além de possuir hábitos culturais específicos, constitui em primeiro lugar e antes de mais nada um lugar de comunicação, de raciocínio coletivo, baseado na experiência e na capacidade de ajuizar, de decisão e de ação, com o fim de resolver questões ou problemas de toda espécie relacionados de perto ou de longe com a sua missão, e isto tanto no plano das operações como no plano da gestão [...] a informação deve ser considerada como um todo gerido sistematicamente, coordenado, harmonizado, objeto de uma política clara (ROUSSEAU; COUTURE, 1998, p. 62).

O conceito de informação é amplo e utilizado por vários domínios. A aplicação da gestão da informação, sob o ponto de vista que interessa para os arquivos, recai sobre a informação orgânica registrada nos documentos decorrentes de funções e atividades desempenhadas pelos seus titulares em determinado ambiente administrativo ou mesmo particular.

Enquanto disciplina autônoma, a Arquivologia refere-se à condição da informação que "deve ser registrada em um suporte material e ser resultado do cumprimento da missão da organização" (SOUSA, 2009, p. 1); um indicativo, portanto, de que as informações orgânicas são originadas à medida que as instituições ou pessoas produzam documentos de arquivo para o pleno exercício de sua existência formal. Ainda em termos de qualificador, tratam-se das informações "registradas com natureza arquivística atribuída" (LOPES, 1997, p. 37), que, a princípio, se expressam no uso restrito de quem as produziu ou acumulou. Entretanto, a natureza atribuída advém das razões que justificam a produção das informações orgânicas, ou seja, os elementos do contexto que, em geral, não se encontram nos documentos, mas em seus vínculos e articulações não explícitas.

A especificidade dos documentos de arquivo é condicionada à sua característica mais relevante: a informação orgânica, que Lousada e Valentim (2010, p. 364) conceituam como "produto das atividades executadas na organização, no contexto do exercício das funções administrativas, o registro físico das transações de uma determinada atividade, tarefa ou tomada de decisão", e reafirmam que a finalidade dos arquivos é de prova administrativa e jurídica. Produto das funções e atividades de seus titulares, sejam eles instituições ou pessoas, públicas ou privadas, os arquivos não podem ser desvinculados de seu referencial contextual para fins de representação, pois segundo Camargo (1994, p. 15): 
[...] a informação, nesse sentido, é parte integrante do documento, este, por sua vez, é parte de um coletivo muito especial a que denominamos arquivo. Em sua acepção clássica, arquivo é o conjunto de documentos que, independentemente da natureza ou do suporte, são reunidos por processo de acumulação ao longo das atividades de pessoas físicas ou jurídicas, públicas ou privadas, e conservados em decorrência de seu valor.

Neste sentido, as organizações que conseguem compreender a importância da gestão das informações orgânicas devem buscá-las não de forma explícita no próprio documento, mas sim, no seu contexto de produção, que define se o documento possui valor primário - controlar, realizar uma atividade, subsidiar a tomada de decisões imediatas - ou secundário - probatório de ações passadas e com caráter informativo acerca de pessoas, fatos e decisões passadas, sendo úteis para a pesquisa histórica e a memória ${ }^{1}$ institucional.

O desafio da gestão da informação nos arquivos perpassa, segundo Lopes (1997, p. 25) pela reconstrução da Arquivística, privilegiando a pesquisa para além da técnica, o que envolveria o desenvolvimento de metodologias ligadas a "investigação acurada dos problemas gerados pela presença das informações registradas de natureza arquivística". E ainda, contempla a valorização da missão institucional, do contexto de criação dos documentos, da definição de uma política de gestão da informação e das relações com outras áreas. Portanto, as organizações que reconhecem a importância da gestão da informação orgânica logram um diferencial competitivo.

\subsection{Documento fotográfico de arquivo}

A fotografia é entendida como técnica e também como "suporte de informação que apresenta imagem obtida com ajuda de um processo fotográfico" (ROUSSEAU; COUTURE, 1998, p. 290). As fotografias como documentos de arquivo, em geral, ilustram os documentos textuais, de modo a melhor detalhar a informação que se pretende transmitir. O termo "documento fotográfico", na abordagem do Grupo de Pesquisa em Acervos Fotográficos (GPAF),

\footnotetext{
1 "A memória é afinal uma faculdade que esquece, selecciona, distorce" (ROUSSEAU; COUTURE, 1988, p. 76).
} 
[...] es comprendido en su sentido más amplio, abarcando la diversidad de los procesos técnicos, siendo preferente el uso de término "documentos fotográficos" para los documentos imagéticos generados por todos los procesos de captación fotográfica de imágenes, incluyéndose los digitales. Sin embargo, existen otros investigadores que defienden el uso de la expresión "documentos fotográficos" apenas para los que resultan de los procesos fotoquímicos. Aquellos que resultan de procesos digitales no pueden llamarse fotografías, sino "imágenes digitales", tanto por su naturaleza numérica como por la cuestión de la ruptura referencial. Dicha corriente de pensamiento considera que la imagen digital no mantiene un "vínculo umbilical" con el referente, así como lo tiene la imagen fotográfica (calco fotoquímico del cuerpo referenciado), por basarse, o ser alterada, por cálculos algebraicos (REZENDE; LOPEZ, 2014, p.172)².

Os documentos de arquivo possuem características específicas que remetem a sua gênese e se constituem como prova. Neste sentido, estas devem ser compreendidas conforme o contexto original de sua produção, contribuindo para que um conjunto documental seja representante da organicidade institucional ou pessoal, conforme indica Lopez (1999, p. 49):

O documento de arquivo diferirá de uma coleção ou de um banco de dados, ou, [...], de um banco de imagens. $\mathrm{O}$ arquivo abandona a ideia de unidade ou de documento único, uma vez que nos arquivos a organicidade fará com que entendamos os documentos agrupados em séries de acordo com as atividades responsáveis por sua geração.

De fato, abordar a gênese do documento fotográfico tem por objetivo entender os aspectos que remetem aos motivos da sua criação e os elementos que caracterizam o documento fotográfico como prova das atividades daqueles que os produzem. Tradicionalmente, as fotografias nos arquivos têm sido valorizadas pelo interesse que despertam sobre as imagens registradas e, não raro, são tidas como expressões fidedignas do instante retratado, capazes de possibilitar a compreensão do passado por meio das imagens.

2 Em português: "É compreendido em seu sentido mais amplo, abarcando a diversidade dos processos técnicos, sendo preferente o uso do termo "documentos fotográficos" para os documentos imagéticos gerados por todos os processos de captação fotográfica de imagens, incluindo-se os digitais. No entanto, existem outros pesquisadores que defendem o uso da expressão "documentos fotográficos" apenas para os que resultam dos processos fotoquímicos. Aqueles que resultam de processos digitais não podem chamar-se fotografias, se não "imagens digitais", tanto por sua natureza numérica quanto pela questão da ruptura referencial. Dita corrente de pensamento considera que a imagem digital não mantém um "vínculo umbilical" com o referente, assim como não tem a imagem fotográfica (reprodução fotoquímica do corpo referenciado), por basear-se, ou ser alterada, por cálculos algébricos". 
Embora tais particularidades confiram aos documentos fotográficos uma condição de representantes verídicos da realidade, quando comparadas a outros documentos, tem-se aí uma falácia elaborada ao longo do tempo, como argumenta Madio (2012, p. 56):

[...] a suposta objetividade da fotografia vai sendo montada e reforçada, ao longo dos anos, pelo seu constante uso, como forma comprobatória dos acontecimentos, dos lugares e das personalidades, em livros, jornais, revistas, documentos pessoais e públicos, identificações policiais, entre outros meios, que mostravam a imagem como cópia fiel do momento congelado, eternizado pelas lentes do fotógrafo.

A atribuição de testemunhos de processos que não existem mais pode ter origem na própria evolução da técnica fotográfica como recurso tecnológico. Rousseau e Couture (1998, p. 232) reconhecem tal perspectiva ao afirmarem que o

[...] conhecimento dos principais processos fotográficos e da sua evolução ao longo dos anos é elemento bastante importante, não só para determinar os melhores métodos de conservação próprios dos diferentes tipos fotográficos, mas também para os reconhecer, avaliar e selecionar.

Desde a sua invenção no século $\mathrm{XIX}$, as fotografias são difundidas $\mathrm{e}$ utilizadas para registro das informações imagéticas. Gradualmente se tornaram parte dos acervos dos arquivos.

Por outro lado, ao analisar a natureza do documento fotográfico produzido e acumulado, Lacerda (2008, p. 80) explica que:

[...] a falta de questionamento sobre a metodologia de tratamento desses registros, do ponto de vista de sua natureza documental, deu espaço ao desenvolvimento de uma abordagem que privilegia questões relativas à preservação dos suportes, numa forma de 'compensação metodológica' que tenta suprir a falta de elaboração de um método de organização mais adequado desses documentos.

É preciso destacar no âmbito literário a falta de definição de critérios de tratamento dos documentos fotográficos no que diz respeito à classificação, avaliação e descrição. Para classificar e organizar a literatura, em geral, indica-se o emprego de métodos numéricos simples ou de atribuição de assuntos a partir do conteúdo das imagens, sob a justificativa de facilitar a recuperação e o acesso à informação. Para avaliar, sugerem-se uma diversidade de possibilidades, que podem considerar "critérios gerais de seleção próprios a cada organismo, critérios 
específicos como a raridade da fotografia, a fama do fotógrafo, a qualidade técnica, a qualidade estética pode influenciar a seleção dos documentos fotográficos" (ROUSSEAU; COUTURE, 1998, p. 233).

As tentativas - bem-intencionadas - de conservação dos suportes e de identificação das imagens - aspectos considerados no tratamento e organização dos acervos fotográficos, aliado as exigências de acesso às informações públicas - tem ampliado as perspectivas de disponibilização dos documentos fotográficos em sítios na internet: Assim, "en los últimos años son constantes las propuestas de recuperación y digitalización de fondos y colecciones fotográficas con el fin facilitar la consulta y la visibilidad de los fondos en la Red" (SALVADOR BENITEZ, 2014, p. $322)^{3}$. Mas, à medida que se separam os documentos pelo suporte, as intervenções resultam na alteração da configuração original dos acervos e causam prejuízo à informação orgânica.

Ao procederam conforme o exposto, as instituições fazem uso do marketing institucional e intentam proporcionar alguma visibilidade à coleção fotográfica. Por marketing institucional ou marketing organizacional entende-se as

\begin{abstract}
[...] atividades empreendidas para criar, manter ou modificar as atitudes e comportamentos do público alvo com relação a uma organização. Tanto as organizações com fins lucrativos quanto as sem fins lucrativos praticam o marketing organizacional. As empresas patrocinam relações públicas ou campanhas de propaganda corporativa para "polir" suas imagens. As organizações sem fins lucrativos, como igrejas, universidades, instituições de caridade, museus e grupos artísticos, fazem o marketing de si mesmas com o objetivo de levantar fundos e atrair membros ou patronos (KOTLER; ARMSTRONG, 1999, p. 461).
\end{abstract}

A utilização do conteúdo como fundamento de gestão das informações e divulgação de documentos fotográficos de arquivo incorre em pelo menos dois riscos. O primeiro é relacionado à ambiguidade que a influência das imagens pode gerar na atribuição da classificação, o que pode dificultar a recuperação dos documentos. E o segundo é o comprometimento do contexto de produção, pois, conforme alerta Lopez (2009, p. 161),

\footnotetext{
${ }^{3}$ Em português: "Nos últimos anos são constantes as propostas de recuperação e digitalização de fundos e coleções fotográficas com o fim (a finalidade) de facilitar a consulta e a visibilidade dos fundos na rede (Internet/rede de computadores/web)."
} 
[...] esse tipo de organização traz sério risco de comprometer tanto o valor probatório de documentos de primeira e segunda idades, como o acesso ampliado aos documentos permanentes, caso o documento imagético disponibilizado não seja devidamente contextualizado.

E ainda é insuficiente para o resgate do contexto arquivístico, uma vez que a informação da imagem não expõe os motivos que levaram à criação e guarda do documento fotográfico.

Em âmbito internacional, a discussão sobre a fotografia percorre, entre outros enfoques, a tentativa de identificar suas diferentes utilidades como, por exemplo, a patrimonial. Neste sentido, Vigil (2014, p. 31) assevera que a "internet es el medio de difusión del patrimonio cultural y fotográfico, y el desarrollo de contenidos en portales y webs es inseparable de la formulación de políticas con el fin de visibilizar los fondos"4. A existência de problemas comuns em âmbito internacional relacionada ao tratamento do documento fotográfico expõe a necessidade da ampliação de ações em prol do tratamento e da análise do documento fotográfico com vistas à garantia da preservação e do acesso.

Uma das necessidades apontadas por Boadas (2014) é a criação de diretrizes gerais que envolvam aspectos de compartilhamento, convergência e atuação em rede, que observam as particularidades do documento fotográfico com atuação transversal. Destarte, é preciso considerar a participação de equipes multidisciplinares com o objetivo de contemplar as diversas nuances do tratamento do documento fotográfico de arquivo, "como parte integrante [...] todo el material documental textual que le esté directamente vinculado" (BOADAS, p. 2014, p. 20)5.

Assim, é possível afirmar que a discussão sobre o tratamento dos documentos fotográficos de arquivo é reconhecida como uma demanda internacional que transita entre os estudos acerca da representação dos contextos de produção e as formas de uso e disponibilização do documento fotográfico. Outra abordagem envolve a questão patrimonial que, para alguns, deve estar alicerçada em políticas regionais, nacionais ou internacionais, que promovam a preservação e o acesso.

\footnotetext{
${ }^{4}$ Em português: "Internet é o meio de difusão do patrimônio cultural e fotográfico e o desenvolvimento de conteúdos em portais da web é inseparável da formulação de políticas com o fim (a finalidade) de visibilizar (tornar visível/dar visibilidade aos) os fundos".

${ }^{5}$ Em português: "[...] como parte integrante [...] todo o material documental textual que esteja diretamente vinculado".
} 


\subsection{Fluxos documentais}

Os fluxos documentais podem ser entendidos como o curso que os documentos percorrem em uma estrutura organizacional, de forma programada e estruturada, com a finalidade de cumprir os objetivos para os quais são criados. $O$ andamento é determinado pela tramitação: a passagem dos documentos por diferentes instâncias de competência que registram as decisões e ações administrativas necessárias à solução de demandas administrativas, necessárias à comprovação de funções e atividades dos produtores de arquivos.

O estudo dos fluxos documentais pode ser inserido como uma etapa da gestão de documentos, que inclui os procedimentos referentes aos seguintes aspectos: produção, controle, armazenamento, uso, arquivamento, difusão e destinação dos documentos de arquivo, conforme explica Valentim (2012, p. 18):

[...] a gestão documental envolve diferentes atividades que abrangem todo 0 ciclo documental, de forma sucinta pode-se destacar: i) levantar, identificar e conhecer o estatuto, regimento, regulamentos e os atos administrativos da organização; ii) identificar e mapear os processos documentais; iii) identificar e mapear os fluxos documentais; [...] iv) elaborar atos administrativos (resoluções, portarias, normas administrativas, normas técnicas, instruções de serviço, etc.) com o objetivo de reger os fluxos documentais.

O desenvolvimento das atividades administrativas se dá por uma multiplicidade de caminhos, conforme as ações ou operações definidas em cada contexto institucional, visando um resultado. Tais atividades,

[...] devido à sua natureza e à dos resultados gerados, podem ser enquadradas na forma de processos organizacionais que, de forma integrada, trabalham no sentido de promover a consecução dos objetivos principais da organização, diretamente relacionados a sua missão (GESPÚBLICA, 2006).

As informações sobre o funcionamento, a estrutura e os processos organizacionais subsidiam a elaboração dos fluxos documentais e são úteis para a compreensão dos documentos arquivísticos como integrantes de um conjunto dotado de organicidade. Neste sentido, é preciso analisar como um todo o corpo de documentos (SCHELLENBERG, 1980), os quais espelham as ações a eles 
relacionadas, não somente àquelas que são a razão de ser das organizações - as atividades fins, mas também aquelas de natureza meio.

Por meio da identificação dos fluxos documentais faz-se importante entender quais são as etapas, os elementos envolvidos, e ainda, a sequência de operações que caracteriza a execução dos processos e fluxos de trabalho. De fato, os processos encontram-se inseridos nos fluxos de trabalho. Relativamente à sua etimologia, "processo" é uma palavra relacionada com percurso, que designa avançar ou caminhar para a frente. Originada do latim procedere, significa método, sistema, maneira de agir ou conjunto de medidas tomadas para atingir algum objetivo. Sobre a questão, Cunha (2012, p. 5) entende que os processos:

[...] são formas de sintetizar as atividades de trabalho em organizações administrativas. Eles direcionam as ações e as rotinas por meio de sua composição. Seus objetivos geram resultados definidos a fim de facilitar a organização e agregar valores à instituição. Embora muitas vezes os processos sejam taxados, pejorativamente, de burocracia eles são necessários para o andamento das instituições administrativas.

Repetidos de maneira recorrente dentro da organização, os processos são a junção de atividades que congregam para a realização de um objetivo global (SALERNO, 2008). Eles se distinguem tanto em sua hierarquia como na capacidade de geração de fluxo, seu papel na organização, na sua relação com a organização e toda sua estrutura. Para Gonçalves (2000), podem ainda ser relacionados à essência da organização, como, por exemplo, os processos de negócio; podem ser essenciais para a produção de resultado para os clientes, como, por exemplo, os processos organizacionais; e, podem realizar as ações para dar suporte a todas as áreas da empresa, como, por exemplo, os processos gerenciais.

O mapeamento - identificação das etapas do processo - e a modelagem representação gráfica dos processos - têm sido muito utilizados pelas instituições como ferramenta gerencial de análise dos fluxos de trabalho e também de comunicação. À medida que são avistados os procedimentos que precisam ser modificados, tais como: a complexidade na operação, a redução de custos, as falhas de integração, as atividades redundantes, as tarefas de baixo valor agregado, os retrabalhos e o excesso de documentação, a gestão com base em processos proporciona tanto a otimização daqueles já existentes, quanto a formulação de estratégias para aumentar e melhorar os resultados dos negócios ou serviços. 
Na perspectiva arquivística, o mapeamento e a modelagem dos processos, bem como dos fluxos documentais é uma iniciativa complexa. Grande parte da dificuldade aqui existente encontra-se na dependência das informações acerca das rotinas, pessoas envolvidas, competências e decisões tomadas, o que não está registrado nos próprios documentos, tampouco os fotográficos, mas sim, no contexto arquivístico, que nem sempre é rastreável.

Os arquivos manifestam-se a partir dos processos administrativos das organizações, formando sistemas específicos de informação cujo fluxo é decorrente do conhecimento acumulado sobre aqueless que geraram ou estão gerando informações registradas (LOPES, 1997), o que impacta na qualidade do trabalho de mapeamento dos fluxos dos documentos.

Ao se afastar da perspectiva conteudista, o conhecimento dos fluxos documentais aplicado aos documentos fotográficos permite uma visão panorâmica das etapas de criação dos documentos de arquivo. Pode ainda facilitar o entendimento das relações hierárquicas e de competência por onde a informação orgânica circula; e ainda, favorece a representação dos caminhos por onde os documentos tramitam no contexto organizacional, por meio da elaboração de fluxogramas.

Associado aos estudos diplomáticos e tipológicos, possibilita a formação de uma metodologia de representação gráfica, fazendo uso dos símbolos padronizados, que evidenciam uma sequência lógica das etapas de realização de um processo de trabalho. A utilização da referida metodologia permite a visualização detalhada das relações existentes entre os envolvidos nos processos decisórios, ou seja, os atores (organização, setor, cargo, grupo de pessoas) que participam do processo de trabalho. Em tal perspectiva, o foco mudaria para os documentos de arquivo produzidos durante a tramitação. Assim, o fluxo documental se apresenta como a conformação do caminho que o documento percorre durante sua tramitação, que é regulado por uma norma de procedimento administrativo (BUENO, 2013).

$\mathrm{Na}$ maioria das instituições de arquivo e nos arquivos das instituições, o princípio supramencionado é ignorado, fazendo uso de

[...] critérios originários das bibliotecas, coerentes com a tradição de ali se depositarem as obras e os demais papéis dos escritórios. Dessa perspectiva, os documentos são tratados um a um, gerando unidades descritivas autônomas [...] sem levar em conta o contexto em que foi produzido (CAMARGO; GOULART, 2007, p. 37). 
Os impactos resultantes da visão outrora apresentada se materializam na transformação dos acervos arquivísticos em coleções desconectadas das razões que Ihes deram origem, o que prejudica o caráter probatório dos arquivos. Tradicionalmente, os documentos fotográficos de arquivo são aqueles que mais "sofrem" este tipo de tratamento individualizado.

Quando produzem e acumulam quantidades enormes de imagens para a realização de alguma atividade administrativa, as instituições potencializam as possibilidades de utilização dos registros fotográficos, tal como a composição de diferentes documentos, entre os quais: a entrevista, a matéria, a notícia ou a reportagem jornalística para publicação em qualquer canal de comunicação (site institucional, jornal impresso, telejornal etc.) ou material de publicidade, por exemplo.

Enfim, o estudo dos fluxos de produção dos documentos deve partir da compreensão das funções ou objetivos que fundamentam a necessidade de documentar para fins de prova, o que pode convergir com o fluxo de produção do documento fotográfico de arquivo enquanto integrante de um documento textual como os citados acima. 


\section{ASSESSORIAS DE IMPRENSA}

\subsection{A construção da imagem institucional}

A atividade especializada de intermediar as relações entre uma organização e a imprensa é denominada comunicação empresarial, organizacional ou institucional. Inclui o conjunto das atividades de comunicação da instituição e envolve técnicas de jornalismo, relações públicas e publicidade convergindo para o gerenciamento da imagem da organização a qual está vinculada. Em geral, essa é uma competência das assessorias de comunicação social ou das assessorias de imprensa que, para Lopes (2003), são estruturas que têm as atribuições básicas de facilitar o acesso dos grupos externos às realizações de uma empresa ou instituição, por meio de uma linguagem simples e organizada, mediada pelos meios de comunicação, além de promover a integração e a satisfação de segmentos internos.

Surgidas a partir da necessidade promover alguma interação entre as organizações empresariais e governamentais com seus clientes - formadores de opinião, consumidores, fornecedores, trabalhadores, parceiros - as atividades dessas estruturas se agregam em tarefas comuns que, no entanto, não se confundem. Por isso, na sequência, faremos uma breve diferenciação entre os conceitos de assessoria de imprensa, assessoria de comunicação e relações públicas. O Manual de Assessoria de Comunicação/Imprensa da Federação Nacional dos Jornalistas (FENAJ) (2007, p. 7) apresenta o conceito de assessoria de imprensa, conforme se segue:

[...] é o serviço prestado a instituições públicas e privadas, que se concentra no envio frequente de informações jornalísticas, dessas organizações, para os veículos de comunicação em geral [...]. Um trabalho continuado de Assessoria de Imprensa permitirá à empresa criar um vínculo de confiança com os veículos de comunicação e sedimentar sua imagem de forma positiva na sociedade.

O mesmo documento informa que as assessorias de comunicação seriam uma ampliação das atividades das assessorias de imprensa ocorrida devido à valorização da atuação dos jornalistas em áreas estratégicas como a elaboração de planos de comunicação. Tais planos, de caráter mais abrangentes, teriam impacto não apenas junto à imprensa, mas, seriam capazes de posicionar "as organizações 
de forma a estabelecer uma interlocução com ética e responsabilidade social, comprometida com os valores da sociedade junto aos seus mais diversos públicos" (FENAJ, 2007, p. 7), com o objetivo de alcançar uma eficiência na comunicação.

Quanto às relações públicas seriam o "conjunto das técnicas concernentes às comunicações de uma empresa com os grupos aos quais não pode opor-se ou misturar-se, a fim de manter boas relações com os diversos setores da opinião pública" (AUGRAS, 1978, p. 78). Em outras palavras refere-se à atividade de estabelecer canais diretos de comunicação com todos os tipos de público que uma organização deseja alcançar. É a área responsável pela criação, planejamento e execução de programas completos de comunicação com foco na "integração e mútua compreensão entre uma organização pública ou privada e todos os grupos aos quais está ligada direta ou indiretamente", como conceitua a Associação Brasileira de Relações Públicas (ABRP) (2016).

A despeito das especificidades das atividades de cada área, as práticas estão interligadas e, conforme indicam Figueiredo e Nassar (1995), o papel dessas estruturas é informar à sociedade os interesses, a forma como as empresas pressionam e se relacionam com os governos e as instituições governamentais. Esse relacionamento seria determinante para seu crescimento e prosperidade e, quando fundamentado em estratégias de gestão do fluxo das informações, influenciaria na manutenção da confiança e integridade da organização perante a sociedade.

Administrar as informações no contexto institucional depende mais da infraestrutura (pessoal, espaço físico e equipamentos) que da designação da nomenclatura do setor. Assim, pode-se afirmar que eficácia dos planos de comunicação organizacional está no inter-relacionamento entre as atividades de relações públicas e assessorias de imprensa, pois "para sobreviver, a empresa necessita criar mecanismos de informação que lhe capacitem conhecer o ambiente onde atua, o mercado onde deverá competir e o próprio ambiente interno que congrega sua estrutura" (REGO, 1986, p. 58). 
Embora existam algumas distorções, talvez decorrentes da confusão na caracterização dessas atividades, nas instituições brasileiras prevalece o uso do termo assessoria de imprensa. Sob essa designação podem ser incluídas ainda as funções de publicidade e propaganda ${ }^{6}$, que não serão detalhadas nesta pesquisa.

Por outro lado, Kopplin e Ferrareto (2001) indicam que o conceito de assessoria de imprensa está associado a dois aspectos fundamentais: a necessidade de divulgar opiniões e realizações de um indivíduo ou grupo de pessoas e a existência de um conjunto de instituições conhecido como meios de comunicação. Ao fomentar a publicação e difusão de seus atos, as organizações públicas ou privadas, possibilitam a renovação das relações com a sociedade e o cidadão pois, "a transparência é dada por uma comunicação a que qualquer pessoa pode ter acesso e entender" (FIGUEIREDO; NASSAR, 1995, p.64). desenvolvimento de ações de comunicação, no âmbito institucional, quando exercida de forma ética e transparente, facilita o controle social e influencia os formadores de opinião.

Apesar da transparência não ser o objetivo explícito das assessorias de imprensa, e sim um princípio pelo qual se exige que a administração pública preste contas de seus atos através dos meios de comunicação, a gestão da imagem institucional de órgãos públicos e das suas relações com os diferentes públicos interno e externo, leva à canalização do fluxo de informações que são exigidas e utilizadas pela sociedade, porque:

[...] quando se fala de transparência pública se quer destacar iniciativas do próprio governo para tornar disponível, ao público em geral, os seus dados, documentos, registros de procedimentos e tudo mais que estiver em processo na administração pública (AMORIM; GOMES, 2013, p. 5).

A disponibilização das informações em qualquer situação, e principalmente no campo governamental, deve ser feita em consonância com os princípios éticos e constitucionais, pois a construção da imagem institucional é calcada no "permanente aprimoramento dos fluxos de comunicação no interior das organizações e perante a opinião pública" (LOPES, 2003, p. 9). Por isso, ações de transparência não se

\footnotetext{
6 "Numa assessoria de comunicação social a função da área de publicidade é planejar, coordenar, administrar campanhas e supervisionar os serviços de agências contratadas ou ainda executar estudos mercadológicos. É responsável pela elaboração de todo o material impresso, como cartazes, folhetos, faixas e produtos como spots - comunicações breves em rádio e tv - e jingles" (LOPES, 2003, p. 20-21).
} 
restringem à simples divulgação de dados orçamentários, de aplicação dos recursos financeiros ou realização das despesas dos órgãos e empresas públicas. Mas, extrapolam esse limite e consideram que também importam ao interesse público informações relacionadas à prestação de serviços, ao processo de gestão administrativa, a interação com a comunidade local, entre outras.

Para isso as atividades das assessorias de imprensa se concretizam com a elaboração de produtos jornalísticos (LOPES, 2003) tais como: edição de jornais, revistas, notícias, reportagens, além da organização de entrevistas (coletivas e individuais). O uso conjunto dos meios de comunicação - jornais, revistas, rádio, televisão e internet, associados aos recursos da tecnologia da comunicação e informação, amplia a capacidade de difusão das informações e veiculação daqueles produtos jornalísticos por meio dos portais corporativos, correios eletrônicos, blogs e mais recentemente, pelas redes sociais. A maneira de dispor de todo esse aparato, no entendimento de Amorim e Gomes (2013), depende da definição de uma política de gestão da comunicação governamental, que conduzirá a arquitetura das ferramentas e das funcionalidades que visam mediar a relação com a esfera pública.

A construção da imagem institucional sugere que a função jornalística, desempenhada pelas assessorias de imprensa, se articule com a execução do planejamento estratégico das organizações, de modo que seja possível desenvolver um processo de comunicação integrada. Para tanto, as características dessas unidades devem ser coerentes com os interesses da instituição a qual são ligadas, sem, no entanto, se render a proveitos políticos ou pressões externas, conforme argumenta Rego (1986, p. 108):

[...] cada organização pode escolher a forma e a posição de sua estrutura
de comunicação no organograma. Mas jamais deve menosprezar as
funções de mediação, controle e integração que dão organicidade e
dinâmica à área. Essas funções indicam a necessidade da estrutura de
coordenação não se subordinar a interesses políticos, nem se sujeitar às
pressões do meio ambiente, porque seu escopo, mais do que de todos os
setores organizacionais, tem como parâmetro fundamental o ajustamento
das partes com a finalidade do equilíbrio.

Sendo assim, os motivos que levam as organizações a constituírem suas assessorias de imprensa podem variar. Porém, implicam a adoção de comportamentos proativos em relação à imprensa, principalmente no sentido de divulgar informações positivas sobre resultados obtidos, lançamentos de produtos, 
ações sociais, programas de interesse coletivo, entre outras que fortaleçam a percepção de uma boa imagem institucional.

\subsection{A Secretaria de Comunicação da Universidade de Brasília}

As assessorias de imprensa podem estar inseridas nas organizações de três formas: dentro da própria instituição, como parte da sua estrutura organizacional; por meio de uma empresa especializada ou de maneira mista, dependendo da necessidade (LOPES, 2003). No caso da Universidade de Brasília (UnB), a Secretaria de Comunicação (SECOM) é constituída como unidade integrante da administração superior, ligada ao Gabinete do Reitor da UnB. A estrutura orgânica da SECOM/UnB está dividida nas seções de Coordenação Geral, Produção de Conteúdo, Relações Institucionais, Assessoria de Imprensa, Design, Fotografia, Desenvolvimento para Web e Coordenação Administrativa. Compõem a equipe designers, fotógrafos, jornalistas, revisoras, produtores culturais e relações públicas, além de profissionais de apoio administrativo e suporte em tecnologia da informação.

A SECOM/UnB é responsável por: gerenciar a imagem da Universidade. É papel da SECOM trabalhar a comunicação interna e externa e desenvolver um trabalho de comunicação integrada, isto é, em convergência com diferentes áreas, de modo a favorecer uma atuação conjunta. O objetivo é divulgar de forma transparente os atos da administração e zelar pela imagem de austeridade, transparência, e de responsabilidade ética, intelectual e administrativa da UnB. Também cabe à SECOM reforçar o papel social da UnB e promover eventos que estimulem estudantes, professores e funcionários a participar das atividades de ensino, pesquisa e extensão da Universidade (UnB, 2012, p. 9).

Conforme anuncia em seu sitio na internet, sob o título de missão, a gestão atual da SECOM estaria pautada nos seguintes princípios: compromisso com a veracidade, zelo pela imagem da UnB, apartidarismo, economicidade, respeito à diversidade e valorização da comunidade acadêmica. E complementa informando que o eixo condutor do trabalho estaria no serviço e na projeção da ciência (UnB, 2016). 
Interessa notar que a seção Assessoria de Imprensa se configura como uma subdivisão da estrutura da Secretaria de Comunicação que, assim como as demais subdivisões, possui atividades específicas. Todavia, essa aparente segmentação do composto da comunicação se articula com a proposta de trabalho da SECOM/UnB expressa no modelo de gestão da comunicação integrada que pressupõe, segundo Kunsch, uma junção da comunicação institucional, da comunicação mercadológica e da comunicação interna, que formam o composto da comunicação organizacional. Este deve formar um conjunto harmonioso, apesar das diferenças e das especialidades de cada setor e dos respectivos subtemas organizacionais (KUNSCH, 1986, p. 150).

Esse modelo vem se consolidando desde a década de 1980 e pode ser reconhecido em boa parte das assessorias de comunicação das instituições brasileiras (CURVELLO, 2011), o qual está centrado em três premissas: uso de diferentes instrumentos de comunicação para transmissão de uma ideia única; integração das atividades de diferentes profissionais de comunicação social (jornalistas, publicitários, relações públicas e administradores de marketing) e, planejamento das ações comunicativas.

A integração proposta por Kunsch prevê a convivência dos diversos sistemas de comunicação organizacional, além de defender a articulação entre as áreas em relação à estratégia organizacional. Situação que para Curvello (2011, p. 98), muitas vezes, está presente como discurso e até orienta as estruturas, mas poucas vezes insere-se como política, como filosofia e como ação. Essa visão é compartilhada por Cruz (2007) ao elaborar artigo acerca dos pressupostos da comunicação integrada no contexto universitário, no qual conclui que as Instituições de Ensino Superior (IES) têm dificuldade em compreender a importância da comunicação organizacional.

Também se percebe que são incipientes no que tange às práticas comunicacionais - comunicação integrada - praticando-as de forma fragmentada e incompleta, uma vez que não desenvolvem um planejamento estratégico de comunicação organizacional, vindo a correr sérios riscos de construção/desconstrução de sua imagem diante dos públicos com os quais mantêm relações (CRUZZ, 2007, p. 16). 
A autora ressalta que mudanças nesse cenário só ocorrerão se, efetivamente, a gestão da comunicação organizacional considerar as dimensões e os fluxos que permeiam a construção/desconstrução das relações pessoais e profissionais nas empresas. O que vai ao encontro da constatação de Kunsch (1992), segundo a qual "não há mais espaço para a concepção de serviços parciais de comunicação nas universidades, com atividades extemporâneas, sem que haja um planejamento integrado e com políticas de comunicação bem definidas" e representa uma mudança substancial na atuação das estruturas de comunicação institucional.

Orientados por essas abordagens e guiados pelo objetivo de caracterizar a SECOM/UnB, seguimos as estratégias delimitadas, ou seja, conceituar as competências específicas e descrever as ações executadas para o cumprimento das suas atribuições. Para isso, pesquisamos nos Relatórios de Autoavaliação Institucional dos anos de 2010 a 2014 as informações sobre a missão institucional os objetivos e as atividades de comunicação desenvolvidas no período.

O referido documento é elaborado pela Comissão Própria de Avaliação $(\mathrm{CPA})^{7}$ da UnB, criada pela Lei 10.861 , de 14 de abril de 2004 - que instituiu o Sistema Nacional de Avaliação da Educação Superior (SINAES). A Comissão é responsável por coordenar os processos de avaliação interna das IES e pelo fornecimento de informações solicitadas pelo Instituto Nacional de Estudos e Pesquisas Educacionais Anísio Teixeira (INEP).

O relatório tem como parâmetro o Art. $3^{\circ}$ da citada Lei, que define as dimensões institucionais das instituições de educação superior que são obrigatoriamente avaliadas com o objetivo de identificar o seu perfil e o significado de sua atuação, por meio das atividades, cursos, programas, projetos e setores, considerando as diferentes dimensões institucionais.

Dentre as dimensões avaliadas, nos limitamos ao inciso que trata da "comunicação com a sociedade", cujos indicadores, entre outros, são: a missão institucional, a comunicação interna e externa no âmbito dos canais e sistemas de informações; e a imagem pública das instituições de ensino superior. Destacamos que, apesar do indicador incluir as atividades de ouvidoria, não são objeto desta pesquisa, por isso não serão aqui comentadas.

\footnotetext{
${ }^{7}$ Anualmente a CPA elabora o Relatório de Autoavaliação da instituição, com informações sobre as dez dimensões de avaliação do SINAES.
} 
Sendo assim, a análise dos Relatórios de Autoavaliação possibilitou a elaboração de dois quadros resumos. O primeiro (Quadro 1) elenca a evolução da missão e dos objetivos da SECOM/UnB no período delimitado - os anos de 2010 a 2014. E o segundo (Quadro 2) apresenta, agrupados conforme os objetivos, os meios e canais de comunicação utilizados pela instituição na execução das ações de comunicação, realizadas e elencadas nos relatórios anuais.

Para a realização do quadro evolutivo da missão institucional considerou-se que a finalidade da missão é clarificar e comunicar os objetivos, os valores e a estratégia adotada pela organização, além disso, para Chiavenato (1999, p. 49), ela funciona como orientador das atividades organizacionais.

Neste sentido, a missão institucional expressa oficialmente pela própria SECOM/UnB serve de auxílio ao procedimento de especificar e escrever as funções ${ }^{8}$ desenvolvidas por ela, e serve aos sistemas arquivísticos de informação. Conforme o Conselho Internacional de Arquivos (2008) as descrições de funções podem ajudar a situar os documentos com mais segurança no contexto de sua produção e uso.

${ }^{8}$ A Norma Internacional para Descrição de Funções (ISDF), do Conselho Internacional de Arquivos (ICA) define função como qualquer objetivo de alto nível, responsabilidade ou tarefa prescrita como atribuição de uma entidade coletiva pela legislação, política ou mandato. Funções podem ser decompostas em conjuntos de operações coordenadas, tais como subfunções, procedimentos operacionais, atividades, tarefas ou transações. 
Quadro 2 - Missão e objetivos da Secretaria de Comunicação da Universidade de Brasília.

\begin{tabular}{|c|c|c|}
\hline Ano & Missão & Objetivos \\
\hline 2010 & $\begin{array}{l}\text { criar e consolidar imagem } \\
\text { pública positiva da UnB; } \\
\text { produzir e gerenciar os fluxos } \\
\text { de informação internos e } \\
\text { externos da UnB; } \\
\text { democratizar o acesso às } \\
\text { informações sobre a UnB. }\end{array}$ & $\begin{array}{l}\text { elevar a autoestima da comunidade acadêmica; } \\
\text { criar e consolidar imagem de excelência acadêmica; } \\
\text { criar e consolidar imagem de eficiência administrativa; } \\
\text { criar e consolidar imagem de transparência das contas; } \\
\text { criar e consolidar imagem de uma universidade } \\
\text { socialmente referenciada; } \\
\text { estimular o zelo e a preservação dos espaços e } \\
\text { patrimônios da UnB. }\end{array}$ \\
\hline 2011 & $\begin{array}{l}\text { gerenciar a imagem da UnB; } \\
\text { trabalhar a comunicação } \\
\text { interna e externa; } \\
\text { desenvolver um trabalho de } \\
\text { comunicação integrada, isto } \\
\text { é, em convergência com as } \\
\text { diferentes áreas, de modo a } \\
\text { favorecer uma atuação } \\
\text { conjunta. }\end{array}$ & $\begin{array}{l}\text { divulgar de forma transparente os atos da Administração; } \\
\text { zelar pela imagem de austeridade e de responsabilidade } \\
\text { ética, intelectual e administrativa da UnB; } \\
\text { reforçar o papel social da UnB; } \\
\text { promover eventos e atividades que integrem estudantes, } \\
\text { professores e funcionários às funções de ensino, pesquisa } \\
\text { e extensão da Instituição; } \\
\text { administrar e manter, por meio da mídia, relação de } \\
\text { transparência e interação com o público da UnB. }\end{array}$ \\
\hline 2012 & $\begin{array}{l}\text { garantir boa imagem; } \\
\text { promover a instituição; } \\
\text { manter a população } \\
\text { informada; } \\
\text { estabelecer relações éticas e } \\
\text { transparentes com os seus } \\
\text { públicos. }\end{array}$ & $\begin{array}{l}\text { gerenciar a publicidade interna e externa da Universidade, } \\
\text { divulgando da maneira mais isenta e transparente possível } \\
\text { o que acontece dentro da Instituição; } \\
\text { reforçar o papel social da UnB e; } \\
\text { promover eventos e atividades que integrem alunos, } \\
\text { professores e funcionários às funções de ensino, pesquisa } \\
\text { e extensão. }\end{array}$ \\
\hline 2013 & $\begin{array}{l}\text { garantir boa imagem; } \\
\text { promover a instituição; } \\
\text { manter a população } \\
\text { informada; } \\
\text { estabelecer relações éticas e } \\
\text { transparentes com os seus } \\
\text { públicos. }\end{array}$ & $\begin{array}{l}\text { gerenciar a publicidade interna e externa da Universidade, } \\
\text { divulgando da maneira mais isenta e transparente possível } \\
\text { o que acontece dentro da Instituição; } \\
\text { reforçar o papel social da UnB e; } \\
\text { promover eventos e atividades que integrem alunos, } \\
\text { professores e funcionários às funções de ensino, pesquisa } \\
\text { e extensão. }\end{array}$ \\
\hline 2014 & $\begin{array}{l}\text { Não explicitado no Relatório } \\
\text { de Autoavaliação } \\
\text { Institucional. }\end{array}$ & $\begin{array}{l}\text { Informa que a principal atribuição da Assessoria de } \\
\text { Imprensa é cuidar da relação entre a UnB e os veículos de } \\
\text { comunicação, receber demandas e fazer a mediação com } \\
\text { professores, pesquisadores e representantes da instituição. }\end{array}$ \\
\hline
\end{tabular}

Fonte: Adaptado dos Relatórios de Autoavaliação (2011 a 2014).

A análise do quadro nos permite identificar alguma compatibilidade entre aos propósitos incluídos na missão institucional da SECOM/UnB e pode ser esmiuçado para localizar ligações entre os objetivos declarados com as possibilidades de produção de fotografias. Essas funções se desdobram em atividades que abarcam 
tarefas, as quais, no contexto arquivístico, se materializam em documentos de arquivo, pois como aponta Lopez (1999, p. 42),

[...] a concepção do documento apregoada pela arquivística está [...] na contextualização da sua produção, graças ao princípio da proveniência que o coloca em uma série que retrata as atividades desenvolvidas pelo órgão de origem, permitindo ainda uma análise conjuntural do momento e dos motivos da sua geração.

Se os objetivos são entendidos como pontos que se pretendem atingir, as atividades são tarefas desempenhadas para o alcance desses objetivos. Assim, para realização de cada uma de suas funções pode haver várias atividades associadas e, em certos casos, algumas atividades podem ocorrer sob diferentes funções. Essa argumentação nos leva a buscar na missão e nos objetivos, conforme apontados no Quadro 2, uma ligação com as possibilidades de produção de fotografia, que foram representados segundo a Figura 1, a seguir.

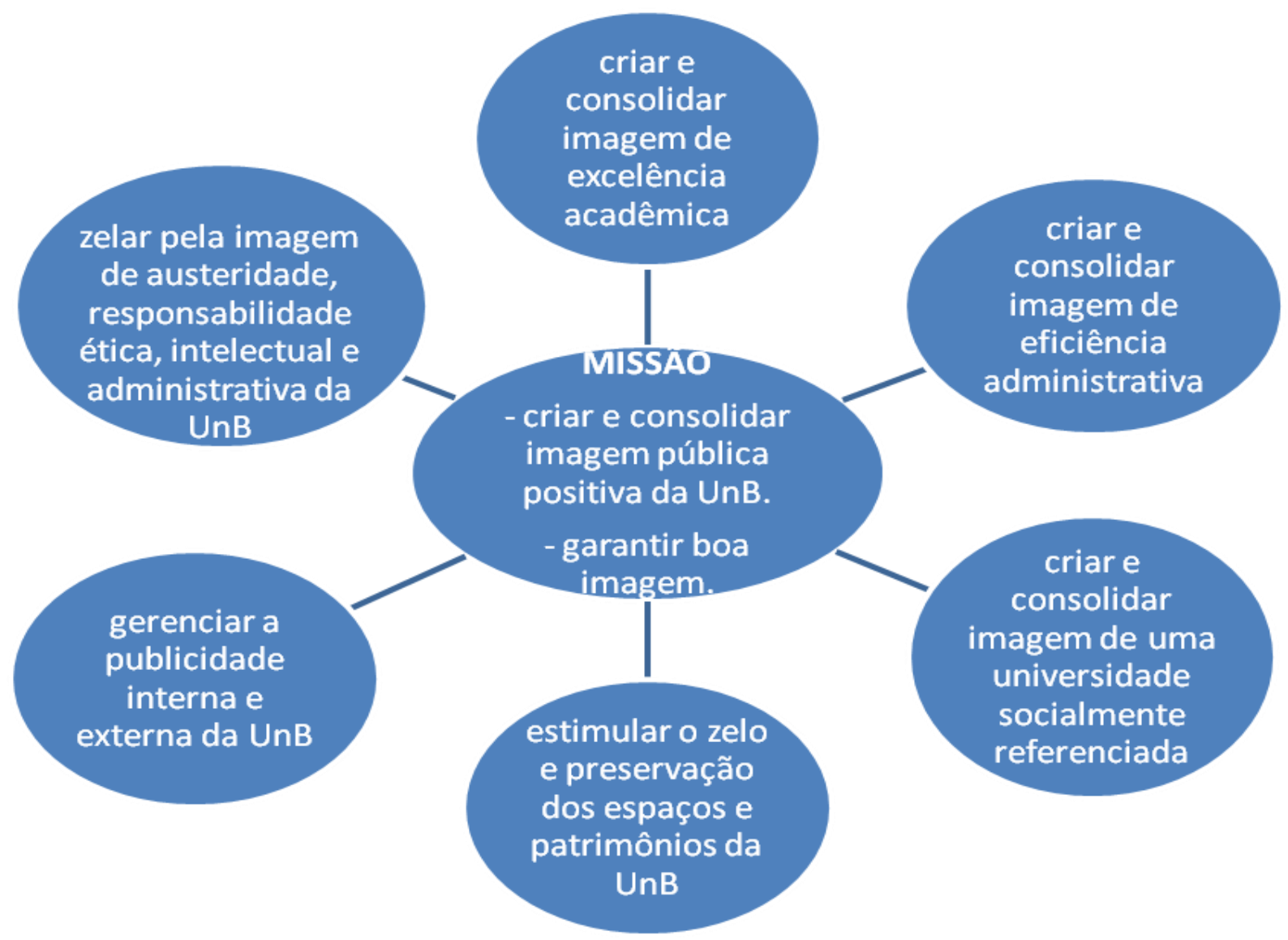

Figura 1 - Possibilidades de produção de fotografias na Secretaria de Comunicação da Universidade de Brasília.

Fonte: Dos autores. 
Para melhor entendimento do gráfico acima, explicamos que no círculo central estão os dois principais itens da missão, selecionados entre os declarados, cuja vinculação com os objetivos representam potencial de gerar fotografias naquele contexto. A partir do centro originam-se os demais círculos que contém os objetivos (atividades) capazes de gerar as fotografias que serão, ou não, utilizadas nos meios e canais de comunicação resultantes das atividades da SECOM/UnB.

Quadro 3 - Meios e canais de comunicação na Universidade de Brasília.

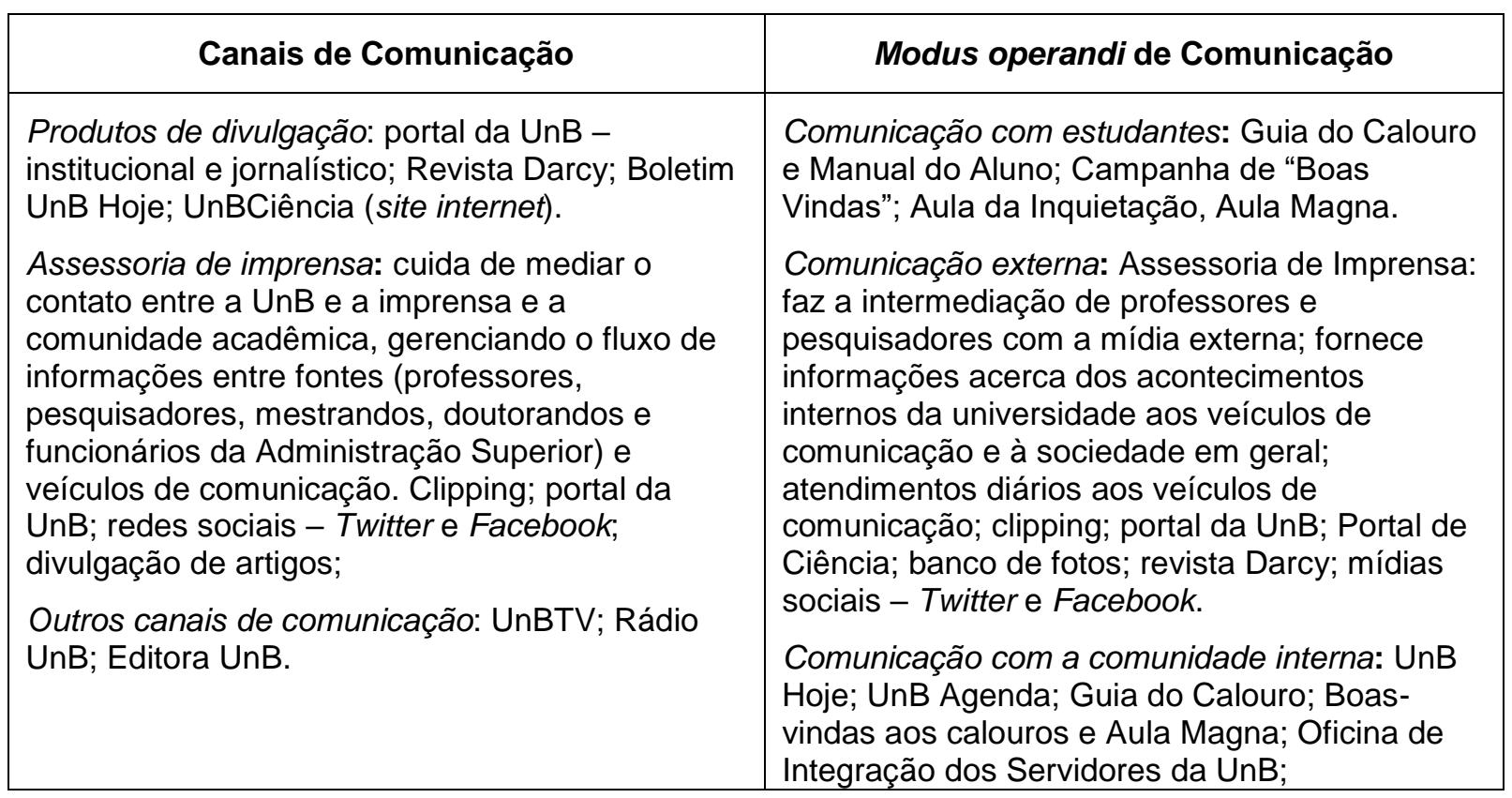

Fonte: Adaptado dos Relatórios de Autoavaliação (2011 a 2014).

Esses canais e meios comprovam a execução das tarefas administrativas e se apresentam em uma variedade limitada de formatos com a finalidade de divulgação interna e externa das informações, entre os quais estão: portal da Universidade (internet); boletim UnB Hoje (impresso e eletrônico); Revista Darcy (impressa e eletrônica); Jornal Campus (impresso) elaborado por estudantes do curso de Comunicação; UnBTV; UnB Ciência (internet); UnB Clipping; Editora UnB e Rádio UnB. Curioso notar que apesar de constar nos relatórios analisados e também no Estatuto e Regimento Geral da Universidade, desde a primeira versão em 1962, a Rádio Universitária inexiste, simplesmente porque não há concessão por parte do governo. 
Além dos canais e meios citados são oferecidos serviços que visam atender demandas de informação, tanto do público interno quanto externo, tais como o banco de pesquisas; o banco de artigos de pesquisadores - ambos vinculados ao site UnB Ciência; e o banco de pesquisadores que propõe concentrar a busca por especialistas que contribuem para a elaboração de reportagens, cuja facilitar é estreitar a relação entre jornalistas e pesquisadores. Consta ainda entre os serviços oferecidos pela SECOM/UnB a publicação diária de informações nas mídias sociais "oficiais" mais conhecidas, como o Facebook e o Twitter.

Destaca-se o banco de fotografias produzido pela editoria de fotografia da SECOM/UnB, que disponibiliza mais de trezentas mil fotos de livre acesso para qualquer pessoa física ou jurídica. Segundo o Relatório de Autoavaliação de 2013 "as fotos dialogam com os textos produzidos tanto para o Portal da UnB quanto para o UnB Ciência e a Revista Darcy, bem como campanhas e eventos realizados pela área de Comunicação Institucional da Universidade" (CPA, p.141). O banco é referenciado como Galeria de Imagens $^{9}$ e está disponível no portal da UnB com link para uma página em nome da UnB Agência registrada no Flickr - aplicativo online de hospedagem, gerenciamento e compartilhamento de imagens fotográficas e vídeos, caracterizado também como rede social.

Porém, aparentemente os recursos de organização colaborativa disponibilizadas pelo aplicativo não são explorados, contendo apenas alguns álbuns que formam dossiês de imagens identificadas por temas que remetem às atividades ligadas ao ensino, à pesquisa e à extensão; a eventos reivindicatórios; ao registro patrimonial; à atividade jornalística e a outros de caráter genéricos, que, respectivamente, são:

a) imagens de eventos de ingresso na universidade: resultado do vestibular, comemoração da aprovação no PAS (Programa de Avaliação Seriada); boasvindas aos calouros;

b) imagens de eventos organizados por outras instituições, mas que envolvem a participação dos estudantes universitários, como a Semana Nacional de Ciência e Tecnologia, do Ministério da Ciência, Tecnologia e Inovação (MCTI) e os Jogos Universitários (JUBs), organizados pela Confederação Brasileira do Desporto Universitário (CBDU).

\footnotetext{
${ }^{9}$ Cf. FLICK. UnB Agência. 2016. Disponível em: <https://www.flickr.com/photos/unb_agencia/>.
} Acesso em: 28 jan. 2016. 
c) imagens de evento de reivindicação organizado pela comunidade acadêmica: 1ㄹ Parada do Orgulho LGBT da UnB, apoiado pela Diretoria de Diversidade da instituição.

d) imagens de edifícios do campus Darcy Ribeiro: Centro de Desenvolvimento Social (CDS); Instituto Central de Ciências (ICC); Biblioteca Central (BCE); Faculdade de Tecnologia (FT) e Restaurante Universitário (RU).

e) imagens de coberturas jornalísticas para os meios de comunicação institucional: estão divididas em três álbuns: o conjunto da Revista Darcy, formado por imagens que ilustram as matérias publicadas na revista; o conjunto sob o título Coberturas Portal UnB, composto por uma miscelânea de imagens que se referem aos eventos de ingresso, imagens dos prédios da UnB, eventos ocorridos no Congresso Nacional, ocupação da Reitoria pelo movimento estudantil, movimento grevista de servidores, etc.; e o conjunto Coberturas Especiais, formado por imagens das reuniões da Sociedade Brasileira para o Progresso da Ciência (SBPC), dos participantes e manifestações ocorridas durante a Conferência Rio+20; e algumas imagens de pessoas (entre elas um ex-reitor) reunidas nas dependências da UnB sem qualquer identificação dos motivos que levaram a sua produção e armazenamento.

f) imagens genéricas, compostas por dois álbuns que, sob a denominação de cotidiano e estudantes registram pessoas, paisagens, edifícios, monumentos, obras em andamento, apresentações artísticas, aulas, protestos de estudantes, etc. Tecnicamente não há diferença entre os grupos de fotografias dos dois álbuns.

Quanto ao compromisso de desenvolver um trabalho de comunicação integrada parece estar expresso nos objetivos de gerenciar os fluxos de informação internos e externos da UnB; trabalhar a comunicação interna e externa; democratizar o acesso às informações sobre a UnB; e manter a população informada.

Embora a proposta da comunicação integrada, no campo conceitual, contemple uma associação das atividades de diferentes profissionais de comunicação social com o uso de diferentes instrumentos de comunicação para transmissão de uma ideia única, essa integração é dependente de um planejamento das ações comunicativas. E isto só faz sentido, no caso da SECOM/UnB, se houver 
sinergia com os objetivos institucionais, valores, missão e visão estratégicas da própria Universidade de Brasília. 


\section{MAPEAMENTO DO FLUXO DE PRODUÇÃO DOS DOCUMENTOS}

Os fluxos documentais, como já foi dito no desenvolvimento deste trabalho, manifestam-se no interior das organizações e formam sistemas específicos de informação oriundos dos processos administrativos. Como os documentos arquivísticos surgem da execução de funções e atividades que geram fluxos de trabalho com o início, meio e fim, o mapeamento dessas atividades interrelacionadas é utilizado como subsidio para a elaboração do mapeamento de processo que resultam na criação desses gráficos. Portanto, a necessidade de conhecer o percurso que os documentos cumprem para atingir os objetivos e finalidades de seus produtores é o fio condutor desta etapa, na qual buscou-se coletar informações in loco diretamente com o (s) envolvido (s) nas atividades.

Para o mapeamento do fluxo de produção dos documentos fotográficos na Secretaria de Comunicação da Universidade de Brasília (SECOM/UnB) (vide Figura 2, a seguir), fez-se uso de uma ferramenta de modelagem de processos denominada Bizagi Process Modeler ${ }^{10}$, embora existam outros aplicativos, a escolha do Bizagi se deve à facilidade de utilização, à gratuidade e porque utiliza notação conjunto de sinais convencionados - padrão BPMN (Business Process Modeling Notation). Criado para ser uma linguagem única para a modelagem de processos de negócio, o BPMN é de fácil assimilação. Entre os elementos BPMN utilizados no fluxograma, estão:

10 Software criado para desenhar, documentar e compartilhar processos, que usa notação BPMN. GESTÃO EMPRESARIAL. Modelagem de processos de negócio (BPM) e seus impactos positivos nas organizações. In: O Gerente, 19 de abril de 2012. Disponível em:

$<$ http://ogerente.com.br/rede/gestao-empresarial/modelagem-de-processos-de-negocio >. Acesso em: 07 dez. 2015. 
Quadro 4 - Elementos BMP utilizados no fluxograma (continua).

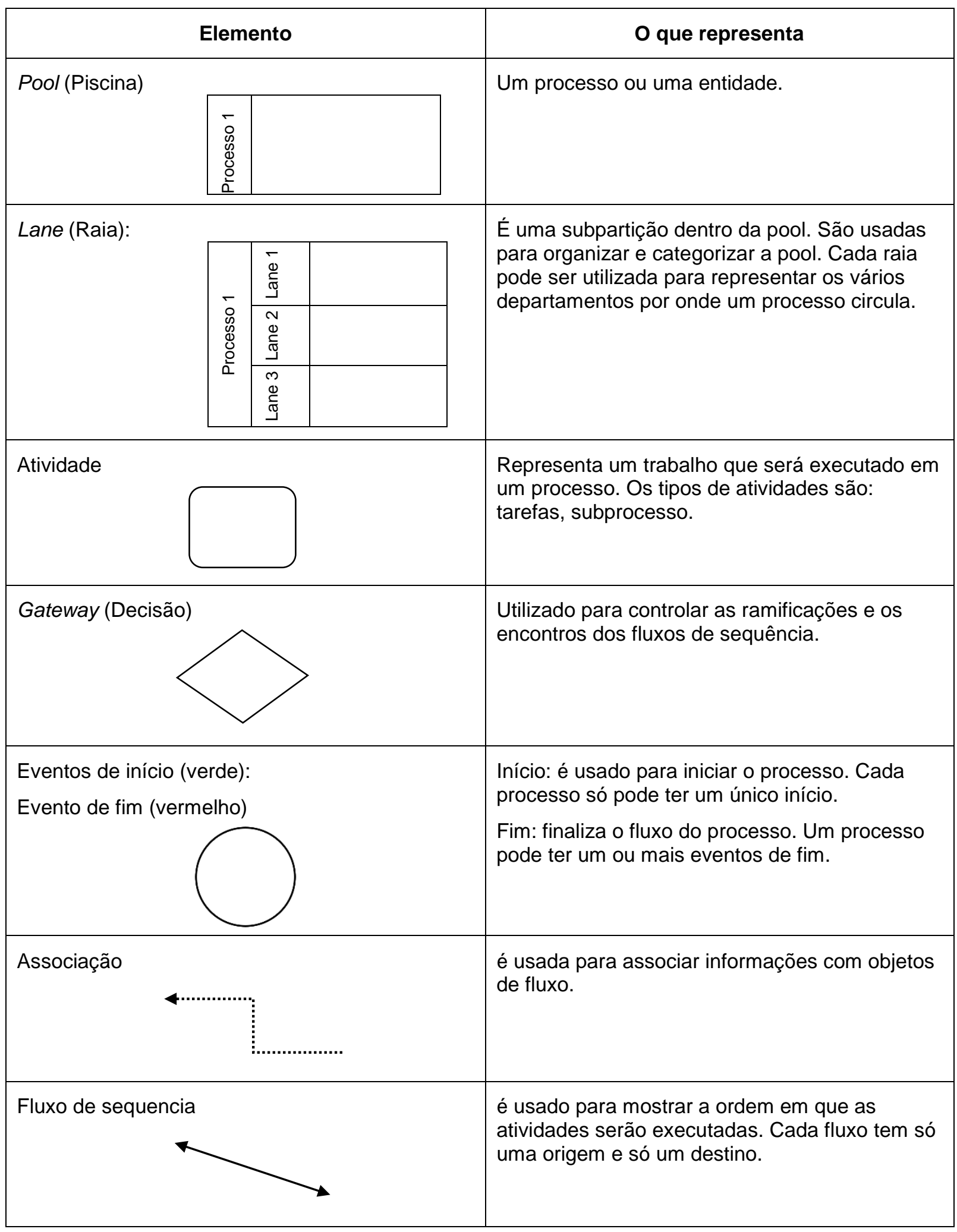


Quadro 4 - Elementos BMP utilizados no fluxograma (conclusão).

\begin{tabular}{|c|c|}
\hline & O que representa \\
\hline Objeto de dados & $\begin{array}{l}\text { Representa os diferentes tipos de objetos } \\
\text { (digitais ou físicos), fornecem informações sobre } \\
\text { como documentos, dados e objetos são usados } \\
\text { e atualizados durante o processo. }\end{array}$ \\
\hline
\end{tabular}

Fonte: Bizagi (2016).

Segundo Monteiro (2014), a modelagem de processos se refere à representação gráfica, de maneira clara e objetiva, do sequenciamento das atividades, da estrutura e do funcionamento básico dos processos. A modelagem dos processos pode ser dividida em dois grandes momentos: a situação atual, "asis", e a situação proposta, "to-be". Para a finalidade desta pesquisa nos limitaremos a representar a situação atual, conforme expresso na Figura 2, a seguir: 


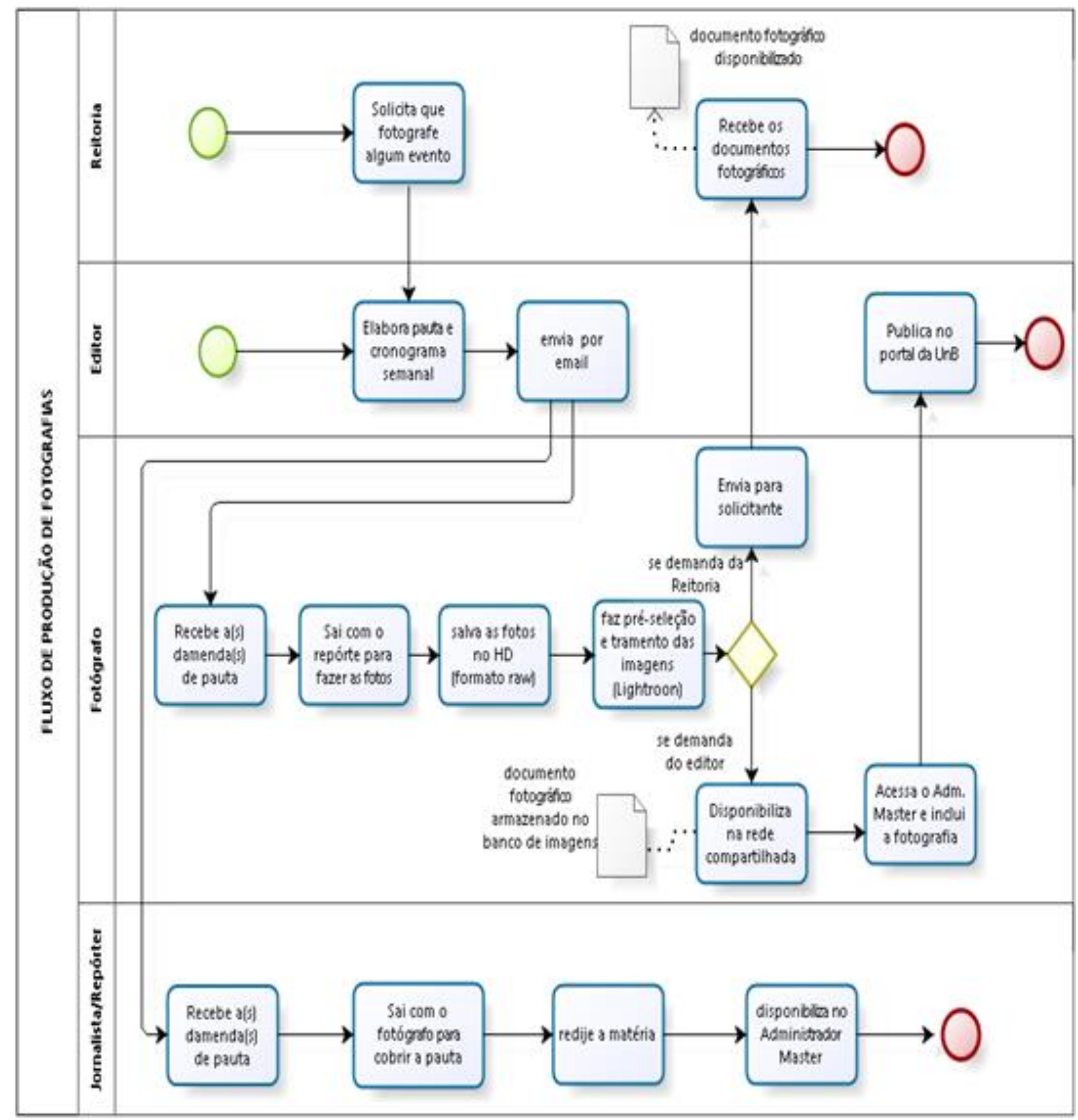

Figura 2 - Fluxo de produção dos documentos fotográficos na Secretaria de Comunicação da Universidade de Brasília.

Fonte: Dos autores.

Os fluxogramas resultantes da modelagem podem ser de dois tipos: o linear e o fluxograma funcional. O fluxograma linear é um diagrama que exibe a sequência de trabalho passo a passo que compõe o processo - esta forma ajuda a identificar retrabalhos, redundâncias ou etapas desnecessárias. Enquanto o fluxograma funcional tem como objetivo mostrar o fluxo de processo atual e quais as pessoas ou grupo de pessoas envolvidas em cada etapa, caracterizando cada operação em relação aos agentes executores (SOUSA, 2008). Neste caso, linhas verticais ou 
horizontais são utilizadas para definir as fronteiras entre as responsabilidades. $O$ modelo funcional foi o escolhido para representar a maneira como, atualmente, são produzidas e utilizadas as fotografias na SECOM/UnB por possibilitar uma visão ampla daquilo que se pretendia mapear, isto é, a gênese documental das fotografias.

As informações foram coletadas por meio de entrevista semiestruturada (vide Apêndice "A") com o fotógrafo da SECOM/UnB, responsável pela Seção de Fotografias, que respondeu a questionamentos acerca dos envolvidos, das etapas de trabalho e recursos tecnológicos utilizados.

Pela análise do fluxograma acima é possível identificar o envolvimento de quatro atores na produção das fotografias, distribuídos em dois setores: Reitoria e SECOM. Sendo que a Reitoria, conforme o art. 25 do Estatuto da UnB, in verbis:

[...] é integrada por: i) Decanatos, com a atribuição de supervisionar e coordenar as respectivas áreas: Ensino de Graduação, Pesquisa e PósGraduação, Extensão, Assuntos Comunitários, Administração, de Gestão de Pessoas e de Planejamento e Orçamento; II) Procuradoria Jurídica; III) Auditoria; IV) Ouvidoria; (Redação dada pela Resolução n. 7/2011, de 24/5/2011, do Conselho Universitário da UnB); e IV) Assessorias (UnB, 2011, p. 17-18).

Os demais envolvidos integram a equipe da Secretaria de Comunicação: Editor, Fotógrafo e Jornalista/Repórter. Outros profissionais, das demais seções internas da SECOM/UnB, como a Assessoria de Imprensa e o Design, podem recorrer ao banco de imagens produzidas para executar suas atividades, porém, na condição de usuários potenciais. Por outro lado, os indicados acima são os que estão diretamente envolvidos na produção das fotografias.

Interessante constatar ainda que grande parte das atividades é realizada pelo fotógrafo, inclusive a inserção das imagens nas matérias jornalísticas. Embora a cobertura da pauta seja feita em parceria com o jornalista, é o fotógrafo quem decide qual imagem comporá a matéria jornalística. O que demonstra sinergia e independência entre as atividades desses dois profissionais.

O fluxograma registra dois eventos de início no processo, o que poderia sugerir uma sobreposição de funções, porque dois setores distintos detém a competência para demandar missões fotográficas institucionais. Isso, inclusive, gera uma inconsistência no uso do padrão BPMN, o qual indica que só deve haver um evento de início para cada processo. Tal situação tem implicações na destinação 
que é dada às fotografias, dependendo da origem da demanda: quando a pauta se origina na Editoria da SECOM, os documentos fotográficos produzidos são armazenados em um banco de imagens da própria Secretaria. Diferente do que ocorre quando a demanda original vem da Reitoria, pois as fotografias produzidas não são armazenadas, mas enviadas ao solicitante. Portanto, a SECOM não as armazena no banco de imagens.

A participação da Reitoria no fluxo de trabalho, originando demandas de pautas fotográficas, indica a possibilidade de elas virem tanto do próprio Gabinete do Reitor e do Vice-Reitor, quanto dos Decanatos, conforme dispõe o artigo do Estatuto da UnB, supracitado, que trata da composição da Reitoria. Essa situação é factível e pode estar relacionada a uma das funções da SECOM/UnB que é "gerenciar a imagem da UnB; esta, por sua vez, seria efetivada por meio da atividade "divulgar de forma transparente os atos da administração". Logo, supomos ter reconhecido um elo entre função e atividade que contextualiza a produção das fotografias.

No entanto, como assinala Camargo (1994) "o significado pleno de cada documento só se evidencia através do vínculo mantido com os outros documentos do mesmo arquivo e que o fundamental é entender o arquivo como conjunto indissolúvel de documentos necessariamente unidos entre si", nossa investigação tratou de localizar nos documentos textuais esse vínculo, porque as fotografias isoladas não são suficientes para evidenciá-lo.

Possivelmente o vínculo contextual seria identificado nos artigos publicados no portal da UnB e ilustrados com as imagens do álbum denominado "coberturas jornalísticas" feitas pela SECOM para os meios de comunicação institucional, na execução das atividades jornalísticas. O que reafirma o argumento segundo o qual os documentos fotográficos são os que não podem, de modo algum, prescindir de elementos contextuais (CAMARGO, 2015) para o cumprimento de sua finalidade arquivística.

Por fim, o fluxograma representa em detalhes as etapas executadas pelos agentes envolvidos no processo. Contudo, destacamos o papel emblemático do fotógrafo, que executa grande parte das tarefas constantes do fluxo de trabalho. A entrevista realizada com o fotógrafo da SECOM/UnB (vide Apêndice "A") revela e complementa as informações sobre suas atribuições e rotinas. Entre elas estão: a definição dos procedimentos administrativos relacionados aos aspectos técnicos de produção e tratamento das imagens, o gerenciamento do banco de imagens e 
também o atendimento às demandas de consultas e solicitações de acesso às fotografias armazenadas.

A entrevista nos permitiu concluir que o fotógrafo é o responsável por grande parte das atividades do fluxo de trabalho que origina o documento fotográfico. Como atua com equipe reduzida o papel do fotógrafo é de grande relevância para o setor, pois ele faz tanto o trabalho de cobertura das pautas jornalísticas, acompanhando um repórter, quanto as tarefas técnicas de pré-seleção e tratamento da imagem.

Além disso, é do fotógrafo a decisão sobre quais e quantas fotografias serão disponibilizadas na rede compartilhada para uso do restante da equipe e, também, é quem insere aquelas que considera mais adequadas para ilustrar determinada matéria que será publicada. $\mathrm{Na}$ entrevista ele revela que faz a gestão do banco de imagens, incluindo identificação das fotografias, classificação, organização, armazenamento, avaliação, recuperação, consultas e disponibilização.

Enfim, com tantas atribuições a relevância do fotógrafo no contexto de produção das fotografias da SECOM/UnB toma proporções que extrapolam sua função técnica. Quanto à gestão do banco de imagens, há ainda algumas questões preocupantes relativas à preservação dos arquivos, como o uso de em dispositivos periféricos (HD externo) para armazenamento e disponibilização; o uso de formatos proprietários (raw e jpg) e o potencial de reuso das imagens, que podem ser republicadas inúmeras vezes. Como por exemplo, a imagem de alguma daquelas autoridades citadas se retratadas numa cerimônia típica do ambiente universitário, como a concessão de título a professor emérito, e armazenada no banco de dados acumulados pela Secretaria de Comunicação institucional, é preservada pelo seu potencial de elaboração de diferentes documentos. Independentemente dos motivos que lhes deram origem. 


\section{FICHA DIPLOMÁTICA DO DOCUMENTO FOTOGRÁFICO}

A proposta de ficha diplomática do documento fotográfico (vide Figura 3 , a seguir) da Secretaria de Comunicação da Universidade de Brasília (SECOM/UnB) tem uma perspectiva instrumental, sem querer esgotar o exercício teórico da análise diplomática, visando contemplar a fotografia na prática administrativa, isto é, como ela ocorre em casos concretos. Para tanto, foi laborado um modelo concebido a partir dos estudos de Duranti (1995, 2010), Lopez (1999), Bellotto (2002), Duranti e Preston (2008) e Rezende e Lopez (2014). O procedimento utilizado foi a análise das características do documento fotográfico produzido em meio digital.

Para a definição dos campos da ficha buscou-se elaborar uma estrutura simples, dividida em três partes: identificação, características extrínsecas e características intrínsecas, conforme exposto na Figura 3, a seguir:

\begin{tabular}{|l|}
\multicolumn{1}{|c|}{ FICHA DIPLOMÁTICA DO DOCUMENTO FOTOGRÁFICO } \\
\hline IDENTIFICAÇÃO: \\
\hline - Produtor: \\
- Autor: \\
- Função da missão fotográfica: \\
- Atividade: \\
- Denominação do documento: \\
- Data: \\
\hline CARACTERíSTICAS EXTRÍNSECAS \\
\hline - Gênero: \\
- Suporte: \\
- Formato: \\
- Dimensão: \\
- Tamanho: \\
- Resolução: \\
\hline CARACTERíSTICAS INTRÍNSECAS \\
\hline Âmbito e conteúdo: \\
Gênero fotográfico: \\
Descritores visuais: \\
Descritores temáticos: \\
Destinatário: \\
\hline
\end{tabular}

Figura 3 - Ficha diplomática do documento fotográfico.

Fonte: Dos autores. 
Diante do exposto, têm-se as definições dos conceitos supramencionados na Figura 3, conforme se segue:

a) Identificação

- Produtor: relativo à proveniência; pessoa a cujo fundo ou arquivo o documento pertence.

- Autor: pessoa física ou jurídica que tem autoridade e competência para emitir o documento arquivístico ou em cujo nome ou sob cujo comando o documento foi emitido.

- Função da missão fotográfica: objetivo de alto nível ou competência prescrita como atribuição de uma entidade coletiva pela legislação, política ou mandato.

- Atividade: tarefa desempenhada por uma entidade coletiva para realizar cada uma de suas funções. Pode haver várias atividades associadas a cada função. Em certos casos, algumas atividades podem ocorrer sob diferentes funções. Atividades abarcam transações que, por seu turno, produzem documentos.

- Denominação do documento: identificação do nome do documento.

- Data: data da produção do documento.

b) Características Extrínsecas

- Gênero: informar qual a configuração do documento conforme o sistema de signos utilizados na comunicação de seu conteúdo. Ex.: gênero imagético.

- Suporte: indicar a base sobre a qual a informação é registrada.

- Formato: informar a configuração física do documento de acordo com especificação de regras e padrões descritos formalmente para a interpretação dos bits constituintes de um arquivo digital. Ex.: raw, jpg, bmp, png, tiff, gif.

- Dimensão: indicar a quantidade de pixels ${ }^{11}$ que formam o arquivo.

- Tamanho: indicar a quantidade de bytes $^{12}$ que compõem o arquivo.

${ }^{11}$ Pixel: é o menor ponto que forma uma imagem digital. Quanto maior for o número de pixels, melhor a resolução da imagem. Utilizado para estabelecer a resolução da imagem em formato digital e padrão de visualização em tela (CONARQ, Resolução n. 31/2010, p. 8).

${ }^{12}$ Agrupamentos formados por conjuntos de 8 bits (binary digit) com os quais os computadores criam, recebem, processam, transmitem e armazenam dados (CONARQ, Resolução n. 31/2010, p. 5-6). 
- Resolução: indicar quantos pontos por polegada (dpi) podem ser encontrados em uma determinada imagem.

c) Características Intrínsecas

- Âmbito e conteúdo: apontar informações relevantes sobre o contexto registrado na imagem. Pode incluir nomes de pessoas, lugares ou eventos, bem como outras situações contidas do conteúdo da imagem.

- Gênero fotográfico: atribuir um gênero para descrever a configuração dos elementos retratados pela imagem fotográfica. Ex.: fotografia documental, retrato, retrato à paisagem, etc.

- Descritores visuais: indicar os temas ou assuntos identificados no documento fotográfico (conceitos abstratos relacionados com os elementos visuais da imagem).

- Descritores temáticos: especificar os itens ou componentes que podem ser identificadas na imagem (elementos objetivos, como prédios, objetos, aspectos do ambiente construído ou natural, etc.).

- Descritores onomásticos: listar os nomes das pessoas retratadas. Incluir nomes de pessoas relacionadas com o documento fotográfico (por exemplo, fotógrafo, produtor de arquivo, proprietário do documento, etc.)

- Destinatário: pessoa para quem o documento arquivístico é direcionado ou para quem se destina (DURANTI; PRESTON, 2008, p. 796). Podemos indicar como destinatário do documento fotográfico, no caso estudado, como ora a própria SECOM/UnB para uso em suas publicações jornalísticas, arquivamento e consulta; ora o demandante do registro fotográfico, como demonstra o fluxograma de produção do documento.

No âmbito da Diplomática o conjunto das características intrínsecas e extrínsecas formam os elementos constituintes do documento - convencional ou digital, formando o aspecto que corresponde à sua natureza diplomática e jurídica, isto é, à sua função, segundo as regras e os usos da instituição que o estabelece (DELMAS, 1996). Entre os caracteres ou elementos externos, extrínsecos, físicos, de estrutura ou formais estão: a estrutura física o gênero, o espaço; o volume que o documento ocupa; a quantidade; o suporte, o formato e até aqueles elementos 
menos corpóreos que alguns autores consideram intermediários, tais como a língua (também entendida como elemento interno), o modo da escrita, a espécie e o tipo (CAMARGO; BELLOTTO, 1996; CRUZ MUNDET, 1994).

Quanto aos caracteres ou elementos internos, intrínsecos, substantivos ou de substância incluem-se o conteúdo, seu assunto propriamente dito, assim como com a natureza da sua proveniência e função. São eles: a proveniência, a função, e, consequentemente, a atividade que lhe concerne e os trâmites pelos quais passou.

Nota-se que a parte da ficha que serve à identificação, embora contenha elementos intrínsecos, foi idealizada para servir de referência contextual sobre o produtor do documento fotográfico. Por outro lado, e de forma complementar o campo destinado às características intrínsecas é formado por elementos de descrição do conteúdo das imagens, mas sem perder de vista o objetivo de buscar identificar sua organicidade em relação às funções e atividades desempenhadas na instituição. Por isso não foram incluídos campos sobre as características da técnica fotográfica, tais como: tipo de equipamento, posição da imagem - se vertical/horizontal, tons de claro e escuro, etc.

Por fim, esclarecemos que esse modelo de ficha diplomática não se esgota nesta proposta, por isso, numa eventual aplicação desta ficha na descrição de arquivos fotográficos, seja o da própria SECOM/UnB ou o de outra instituição, outras informações podem ser incluídas. 


\section{A GESTÃO DA INFORMAÇÃO E OS DOCUMENTOS FOTOGRÁFICOS}

A geração e o acúmulo cada vez maior de informações exigem administração e tratamento específico para efetivação de seu uso nas mais diferentes situações. Há certo consenso entre os autores ao indicar que a gestão da informação envolve os estudos e as práticas gerenciais voltadas para a construção, a disseminação e o uso da informação. E que sua base estaria,

[...] na confluência de três grandes setores da sociedade: a indústria da informação, o mercado das tecnologias da informação e comunicação, e as construções teórico-metodológicas das ciências da informação - estas ditas em minúscula no plural para designar o conjunto de disciplinas e/ou áreas do conhecimento que se dedicam, de alguma forma, ao estudo da informação, em aspectos diversos (SOUZA; DIAS; NASSIF, 2011, p. 58, com adaptações).

Pode-se compreender a gestão da informação em uma divisão de etapas que, segundo Marchiori (2002), parece envolver um compartilhamento dos processos de criação, seleção e avaliação, gerenciamento, divulgação, utilização, preservação e políticas de direitos (privacidade, direitos autorais e outros) relacionados ao trinômio dado, informação e conhecimento. Enquanto que para Choo (2006) essas etapas partiriam da necessidade de informação, e as seguintes seriam aquisição, organização e distribuição da Informação.

Por outro lado, Araújo (1999, p. 155) ao analisar o contexto das práticas sociais de comunicação em que a informação é elemento fundamental, ela indique que é por meio ido intercâmbio informacional que os indivíduos:

[...] tomam conhecimento de seus direitos e deveres e, a partir deste momento, tomam decisões sobre suas vidas, seja de forma individual, seja de forma coletiva. Assim, ao participarem de circuitos comunicacionais, os sujeitos sociais constroem as práticas informacionais. Estas podem ser conceituadas como ações de recepção, geração e transferência de informação que se desenvolvem em circuitos comunicacionais que ocorrem nas formações sociais.

Dessa forma, tentar traçar as linhas de relacionamento da gestão da informação com o fluxo de produção de documentos fotográficos de arquivo, nesta proposta, perpassa pela comparação das etapas da gestão da informação com as práticas realizadas na Secretaria de Comunicação da Universidade de Brasília (SECOM/UnB). Para isso, escolhemos as fases de criação, seleção, utilização e 
divulgação da informação para cotejar com aquelas do ambiente corporativo estudado e os documentos fotográficos produzidos.

Tendo em vista que os documentos fotográficos, mesmo quando produzidos no contexto administrativo, são mais valorizados pelo interesse que despertam sobre as imagens registradas e tidas como expressões fidedignas da realidade, procurouse utilizar o procedimento de comparação entre os conceitos de algumas etapas da gestão da informação com as informações obtidas a partir do caso estudado, com o propósito de tecer argumentos e explicações.

\subsection{Criação, seleção, utilização e divulgação}

Primeiramente, é possível afirmar que a criação da informação se evidencia na própria missão institucional da SECOM, a qual se propõe a "criar e consolidar imagem pública positiva da UnB" e também "garantir boa imagem" (vide Figura 1). Para tanto, são utilizados os documentos fotográficos como elemento complementar aos produtos jornalísticos utilizados nos diversos meios de comunicação, entre eles: a reportagem, a entrevista, o artigo jornalístico.

As possibilidades de uso da fotografia na composição dos diferentes veículos de comunicação - jornais, revistas, televisão - estão potencializadas pela adoção das variações desses veículos via internet, que se vale dos portais corporativos, correios eletrônicos, blogs e, mais recentemente, das redes sociais para a criação de uma imagem institucional. Tal imagem pode estar definida na política de gestão da comunicação institucional que, embora não esteja declarada, sugere que a função jornalística, desempenhada pela Secretaria de Comunicação se articula com a execução do planejamento estratégico da Universidade.

A geração das fotografias acontece a partir de uma demanda de pauta, cuja vinculação com os objetivos se articula com os itens da missão. Assim, as atividades se desdobram na criação e consolidação da imagem de eficiência, excelência acadêmica, transparência dos atos administrativos e também, naquele que talvez seja o mais nobre dos propósitos neste contexto, que é consolidar a imagem de uma universidade socialmente referenciada. Parece discutível que o documento fotográfico de arquivo seja capaz de tanto. 
Quanto à seleção das informações no fluxo de produção das fotografias já se percebe uma mudança de atuação, do coletivo para o individual, ou seja, é uma etapa desenvolvida quase que exclusivamente pelo fotografo. $O$ fluxograma (vide Figura 2) indica que, à medida que ele é o responsável por grande parte das atividades do fluxo de trabalho que origina o documento fotográfico, essa etapa ganha relevância pelo desempenho das técnicas de pré-seleção e tratamento da imagem. Essa seleção inclui a decisão sobre quais e quantas fotografias serão disponibilizadas na rede compartilhada para uso do restante da equipe e, também, quais serão consideradas mais adequadas e selecionadas para ilustrar publicação nas matérias jornalísticas.

Outro aspecto de destaque acerca da seleção envolve a definição dos requisitos técnicos dos documentos fotográficos, ou seja, os equipamentos, formatos e volumes de armazenamento das fotografias selecionadas, seja para uso imediato ou arquivadas no banco de dados. Dessa maneira, a tomada de decisão é centralizada e pode, ainda, se refletir na formação do acervo, na acumulação, armazenamento, e usos do documento fotográfico.

Neste ponto é possível identificar que há um gargalo na gestão de documentos, pois, ao salvar as fotos no HD como o fotógrafo informa na entrevista (vide Apêndice "A"), mesmo se publicadas, elas continuam armazenadas para usos possíveis sem tratamento arquivístico (classificação, avaliação, descrição). Embora tenham sido selecionadas, submetidas a tratamento técnico, e resolução ótima, essas versões tecnicamente tratadas são desconsideradas na publicação, que utiliza um padrão de qualidade condizente com o meio de comunicação, que nem sempre suporta uma imagem de alto padrão. O mesmo ocorre com as demais fotografias não selecionadas para publicação, isto é, são simplesmente acumuladas em meio digital sem tratamento arquivístico.

A discussão que se apresenta é sobre a forma documental, ou seja, o estágio de preparação e transmissão de um documento, que pode ser: minuta, cópia, rascunho, original. Por exemplo, uma vez que a fotografia é inserida numa reportagem, ela passa a fazer parte daquele documento publicado, torna-se indissociável dele, naquele contexto. Entretanto, a mesma fotografia quando vista em separado seria incompleta - com potencial para compor outro documento. Temos então, dois documentos fotográficos, um produzido a partir da missão fotográfica, possível de ser vinculado a uma atividade administrativa. E outro 
associado a um produto jornalístico, como uma informação visual integrante do texto.

Indaga-se se ambos podem ser considerados documentos de arquivo. Dependendo do enfoque que se queira atribuir na definição dos parâmetros da gestão de documentos de arquivo, somente o segundo, talvez, mas essa discussão carece de maiores estudos.

Sobre a condição de utilização dos documentos fotográficos, podemos argumentar em duas direções. Uma relativa à construção da imagem institucional e outra em relação à dispersão do patrimônio documental. A primeira teria subsídio no Relatório de Autoavaliação, que no ano de 2013, afirma haver um diálogo dentre as fotos e "os textos produzidos, tanto para o Portal da UnB, quanto para o UnB Ciência e a Revista Darcy, bem como campanhas e eventos realizados pela área de Comunicação Institucional da Universidade" (CPA, p.141) o que nos leva a identificar a tentativa de articulação entre os veículos de comunicação com a finalidade de atingir uma linha editorial calcada na construção da imagem institucional.

A segunda condição de utilização levanta questionamentos relacionados à disponibilização das fotografias para os usuários, internos e externos à UnB, pois ao enviar documentos fotográficos produzidos a partir de demandas que não são da Editoria da SECOM, há nítida despreocupação com o patrimônio documental. Isso fomenta ainda mais a discussão acerca da forma, pois os usos possíveis dos documentos fotográficos influenciam nos estágios de preparação dos documentos de arquivo, seja nos aspectos técnicos (resolução, versões, formatos), seja nas disponibilizações sem controle para qualquer pessoa que solicite uma cópia da fotografia, como afirmou o fotógrafo (vide Apêndice "A").

E por último, sobre a etapa de divulgação das informações, temos o interessante exemplo do banco de imagem, denominado Galeria de Imagens, que é uma forma de disponibilização dos documentos fotográficos via internet. Ali as fotografias são dispostas em álbuns que formam dossiês de imagens disponíveis para acesso via redes sociais. O que seria uma maneira interativa de divulgação das ações institucionais e consolidação da imagem institucional por meio da utilização do documento fotográfico.

Afinal, a ressalva que se faz é quanto à indexação das informações, pois os temas utilizados para identificar os álbuns ora remetem às atividades acadêmicas, ligadas ao ensino, à pesquisa e à extensão; ora a eventos sem aparente vinculação 
orgânica como os reivindicatórios e a outros de caráter genérico. Ao mesmo tempo em que não há uma categorização das informações, a identificação baseada no conteúdo das fotografias gera confusão, porque há grupos com a mesma designação. Como por exemplo, dos documentos relacionados ao registro patrimonial e à atividade jornalística, podendo causar dificuldades de recuperação das informações. 


\section{CONSIDERAÇÕES FINAIS}

A formação de diferentes modalidades de acervo, requer intervenções metodológicas típicas de cada contexto. A compreensão dos usos do documento fotográfico, respeitada sua condição de arquivo, exige que seja respeitada a característica de conjunto de documentos, acumulados em decorrência de funções e atividades de seu produtor.

Tradicionalmente, o tratamento dado aos documentos fotográficos tem sido no sentido de separá-lo dos demais documentos e analisá-lo a partir da descrição do conteúdo de cada imagem, resultando na desvinculação arquivística decorrente da perda do seu contexto de criação. Esse método de organização despreza os princípios da proveniência e da ordem original, os quais resultam na organicidade que "fará com que entendamos os documentos agrupados em séries de acordo com as atividades responsáveis por sua geração" (LOPEZ, 1999, p. 51). Tratar o conteúdo informacional do documento fotográfico de modo isolado é uma estratégia limitadora do potencial informativo e probatório dos arquivos, além de resultar numa "análise simbólica da imagem" em detrimento da condição de arquivo.

O desenvolvimento desta pesquisa transcorreu na perspectiva dos documentos fotográficos de arquivo da Secretaria de Comunicação da Universidade de Brasília, por meio do mapeamento do processo de produção, com vistas a compreender como ele se relaciona com a gestão da informação. Ancorado no âmbito do Grupo de Pesquisa em Acervos Fotográficos (GPAF) que atua na a aspiração de contribuir nos níveis epistemológico, científico e prático relativos à organização documental, o foco da pesquisa é comprovação de atividades administrativas e também na descrição, acesso e recuperação de informações.

$O$ objetivo de esmiuçar as relações entre os fluxos formais de registro da informação, no que tange à produção de documentos fotográficos de arquivo no contexto específico resultou em algumas convergências e também divergências, em relação às etapas da gestão da informação desenvolvidas no ambiente acadêmico, como o visto no caso da Secretaria de Comunicação da Universidade de Brasília (SECOM/UnB). Esta, ao ser caracterizada para o alcance do primeiro objetivo revelou-se detentora da missão institucional de construção e consolidação da imagem institucional, o que representa uma grande responsabilidade, dadas as peculiaridades da atividade de ensino, pesquisa e extensão. 
O mapeamento do fluxo de produção dos documentos fotográficos de arquivo na SECOM/UnB possibilitou uma rica experiência que envolveu o melhor entendimento do papel dos atores envolvidos, e uma aproximação com a realidade das demandas que principiam a missão fotográfica. Além disso, a representação das fases do processo de criação, utilização e armazenamento das fotografias proporcionou uma visão ampla das atividades, como estão sendo feito atualmente. O que pode suscitar diferentes reflexões sobre o objeto estudado, como detalhamos mais adiante.

A representação do fluxo de produção também facilitou a estruturação da ficha diplomática do documento fotográfico, posto que a Diplomática se concentra na gênese, na constituição interna, na transmissão e na relação dos documentos entre seu criador e o seu próprio conteúdo, com a finalidade de identificar, avaliar e demonstrar a sua verdadeira natureza (DURANTI, 1995). E a utilização do método diplomático oferece condições para a identificação das características de autenticidade e fidedignidade aos documentos de arquivo. Apesar do aspecto instrumental a ficha diplomática elaborada pode servir de subsídio para pesquisas mais aprofundadas sobre as fotografias digitais.

E por fim, esta pesquisa ao traçar as linhas de relacionamento da gestão da informação com o fluxo de produção de documentos fotográficos de arquivo tentou articular as informações levantadas nos objetivos anteriores para formar um painel argumentativo. Essa abordagem comparativa foi valorizada pela grande quantidade de insumos coletados, devido ao fácil acesso às informações. $E$ ainda não se esgotou nas reflexões aqui registradas, podendo ser explorada na análise de outras situações em que o documento fotográfico é utilizado. 
Quadro 5 - Argumentação comparativa entre os objetivos propostos e os resultados obtidos.

\begin{tabular}{|l|l|l|l|}
\hline \multicolumn{1}{|c|}{ Objetivo Específico } & \multicolumn{1}{|c|}{ Estratégia(s) } & \multicolumn{1}{|c|}{ Recurso(s) } & \multicolumn{1}{|c|}{$\begin{array}{l}\text { Resultado(s) } \\
\text { Obtido(s) }\end{array}$} \\
\hline $\begin{array}{l}\text { I. Caracterizar a } \\
\text { SECOM/UnB. }\end{array}$ & $\begin{array}{l}\text { Conceituar as } \\
\text { competências } \\
\text { específicas; } \\
\text { Descrever as ações } \\
\text { executadas para o } \\
\text { cumprimento das } \\
\text { atribuições. }\end{array}$ & $\begin{array}{l}\text { Pesquisa documental e e } \\
\text { bibliográfica. }\end{array}$ & $\begin{array}{l}\text { Identificação da } \\
\text { missão institucional de } \\
\text { construção e } \\
\text { consolidação da } \\
\text { imagem da UnB em } \\
\text { relação às funções de } \\
\text { ensino, pesquisa e } \\
\text { extensão. }\end{array}$ \\
\hline $\begin{array}{l}\text { II. Mapear o contexto } \\
\text { de produção dos } \\
\text { documentos } \\
\text { fotográficos de arquivo } \\
\text { na SECOM/UnB. }\end{array}$ & $\begin{array}{l}\text { Coletar informaçães in } \\
\text { loco; } \\
\text { Elaborar esquema } \\
\text { gráfico do fluxo de } \\
\text { produção (fluxograma) } \\
\text { representando os usos } \\
\text { das fotografias. }\end{array}$ & $\begin{array}{l}\text { Entrevista formal não } \\
\text { estruturada e software } \\
\text { desenho de processos } \\
\text { de trabalho. }\end{array}$ & $\begin{array}{l}\text { Fluxo do documento } \\
\text { fotográfico mapeado } \\
\text { conforme metodologia } \\
\text { BPM e apresentação } \\
\text { de gráfico } \\
\text { representativo dos } \\
\text { usos da fotografia pela } \\
\text { SECOM/UnB. }\end{array}$ \\
\hline $\begin{array}{l}\text { III. Estruturar ficha } \\
\text { diplomática do } \\
\text { documento fotográfico. }\end{array}$ & $\begin{array}{l}\text { Elaborar modelo de } \\
\text { ficha descritiva } \\
\text { adequada ao objeto } \\
\text { documento fotográfico. }\end{array}$ & $\begin{array}{l}\text { Pesquisa bibliográfica } \\
\text { e documento } \\
\text { fotográfico de arquivo. }\end{array}$ & $\begin{array}{l}\text { Ficha diplomática } \\
\text { proposta contendo os } \\
\text { elementos intrínsecos } \\
\text { e extrínsecos } \\
\text { característicos do } \\
\text { documento fotográfico. }\end{array}$ \\
\hline $\begin{array}{l}\text { IV. Traçar as linhas de } \\
\text { relacionamento da } \\
\text { gestão da informação } \\
\text { com o fluxo de } \\
\text { produção de } \\
\text { documentos } \\
\text { fotográficos de arquivo } \\
\text { na SECOM/UnB. }\end{array}$ & $\begin{array}{l}\text { Comparar as etapas } \\
\text { da gestão da } \\
\text { informação com as } \\
\text { práticas realizadas na } \\
\text { SECOM/UnB. }\end{array}$ & $\begin{array}{l}\text { Informações obtidas a } \\
\text { partir do caso e } \\
\text { pesquisa bibliográfica. }\end{array}$ & $\begin{array}{l}\text { Elaboração de um } \\
\text { painel argumentativo } \\
\text { entre as etapas da } \\
\text { gestão da informação } \\
\text { (criação, seleção, } \\
\text { utilização e divulgação) } \\
\text { com o fluxo de } \\
\text { produção de } \\
\text { documentos } \\
\text { fotográficos de arquivo. }\end{array}$ \\
\hline
\end{tabular}

Fonte: Dos autores.

Entre os possíveis desdobramentos que esta pesquisa pode suscitar podemos indicar pelo menos três perspectivas. A primeira seria a possibilidade de influenciar uma política de avaliação dos documentos fotográficos acumulados pela instituição. A definição de critérios arquivísticos capazes de recomendar quais documentos fotográficos serão preservados para guarda permanente, por serem dotados de valor secundário, isto é, aquele que considera as informações sobre o aspecto probatório, histórico ou informativo dos documentos, pode contribuir para melhor gestão dos volumes de fotografias produzidas e acumuladas. 
A segunda perspectiva de desdobramento está relacionada a definição das séries documentais as quais deverão ser reflexo das funções e atividades desempenhadas pela SECOM/UnB. Isto favoreceria o melhor entendimento das características do arquivo da Secretaria de Comunicação, o que inclui as necessidades de investimentos em formação de equipes, compra de equipamentos, treinamento e capacitação, entre outras demandas administrativas.

A terceira perspectiva está relacionada ao aspecto prático de aplicação da ficha diplomática, o que serviria para detalhamento das características intrínsecas do documento na sua condição orgânica. Este aspecto está diretamente vinculado a determinação de sua proveniência e constituição do documento de arquivo. O que é fundamental para o cumprimento das determinações legais de gestão de documentos, incluindo a definição dos procedimentos de produção, uso, tramitação, avaliação e arquivamento dos documentos em fase corrente e intermediária com vistas a sua destinação final. Enfim, é possível especular outros prolongamentos decorrentes deste estudo, porém, nos limitaremos aos citados até aqui. 


\section{REFERÊNCIAS}

ALMEIDA, C. C. Da consciência utilitarista da informação. 2007. Disponível em: <http://www.ofaj.com.br/textos_conteudo.php?cod=591 >. Acesso em: 20 jul. 2014.

ALVARENGA NETO, R. C. D. Gestão do conhecimento em organizações: proposta de mapeamento conceitual integrativo. 2005. Tese (Doutorado em Ciência da Informação) - Escola de Ciência da Informação, Universidade Federal de Minas Gerais, Belo Horizonte, 2005. Disponível em:

<http://www.bibliotecadigital.ufmg.br/dspace/handle/1843/EARM-6ZGNE6>. Acesso em: 20 jul. 2014.

AMORIM, P. K. D. F.; GOMES, W. O estado da transparência digital das capitais brasileiras: um estudo sobre e-transparência fiscal. In: V Encontro da Compolítica, Curitiba, UFPR, 2013. Disponível em: <http://www.compolitica.org/home/wpcontent/uploads/2013/05/GT-04-\%C3\%94\%C3\%87\%C3\%B4-Internet-ePol+\%C2\%A1tica-Paula-Karini-Amorim.pdf>. Acesso em: 20 jul. 2014.

ARAÚJO, E. A de. Informação, sociedade e cidadania: gestão da informação no contexto de organizações não-governamentais (ONGs) brasileiras. Ci. Inf., Brasília, v. 29, n. 2, p. 155-167, mai./ago, 1999.

ASSOCIAÇÃO BRASILEIRA DE RELAÇÕES PÚBLICAS. Definição de relações públicas. 2016. Disponível em: <http://abrpsp.org.br/mercado/definicao-de-rp-daabrp/>. Acesso em: 20 jan. 2016.

AUGRAS, M. Opinião pública: teoria e pesquisa. 3. ed. Petrópolis, RJ: Vozes, 1978.

BLATTMANN, U.; RODRIGUES C. Uso das fontes de informação para a geração de conhecimento organizacional. Perspectivas em Gestão \& Conhecimento, João Pessoa, v. 1, n. 2, p. 43-58, jul./dez. 2011. Disponível em:

<http://periodicos.ufpb.br/ojs/index.php/pgc/article/view/9999/6922>. Acesso em: 22 jun. 2015.

BARRETO, A. A condição da informação. São Paulo em Perspectiva, v. 16, n. 3, p. 67-74, 2002. Disponível em: <http://www.scielo.br/pdf/spp/v16n3/13563.pdf>. Acesso em: 22 jun. 2015.

BELLOTTO, H. L. Como fazer análise diplomática e análise tipológica de documento de arquivo. São Paulo: Arquivo do Estado, Imprensa Oficial, 2002. 
BELKIN, N. J. Information concepts for information science. Journal of Documentation, v. 34, n. 1, mar. 1978. Disponível em:

<http://www.emeraldinsight.com/doi/pdfplus/10.1108/eb026653>. Acesso em: 22 jun. 2015.

BIO, S. R. Sistemas de informação: um enfoque gerencial. São Paulo: Atlas, 1985.

BIZAGI. 2016. Disponível em: <http://www.bizagi.com/>. Acesso em: 22 jan. 2016.

BOADAS, J. Patrimonio fotográfico: propuesta para una gestión eficaz. In: ZALDUA, M. O. (Org.). Del artefacto mágico al píxel: estudios de Fotografía. Madrid: Fadoc. UCM, 2014.

BOADAS, J.; CASELLAS, L. E.; SUQUET, M. À. Manual para la gestión de fondos y colecciones fotográficas. Girona: Biblioteca de la Imagen, CCG Ediciones Ajuntament de Girona (CRDI), 2001.

BORKO, H. Information science: what is it? American Documentation, v. 19, n. 1, p. 3-5, jan. 1968. Disponível em:

<https://www.marilia.unesp.br/Home/Instituicao/Docentes/EdbertoFerneda/k---artigo01.pdf >. Acesso em: 22 jun. 2015.

BRASIL. Ministério do Planejamento, Orçamento e Gestão. Secretaria de Gestão. Guia D simplificação. 2. ed. Brasília: MPOG/SEGES, 2006.

BROOKES, B. The foundations of information science: philosophical aspects. Journal of Information Science, v. 2, p. 125-133, 1980. Disponível em: <http://comminfo.rutgers.edu/ kantor/601/Readings2004/Week3/r4.PDF>. Acesso em: 22 jun. 2015.

BRUYNE, P.; HERMAN, J.; SCHOUTHEETE, M. Dinâmica da pesquisa em ciências sociais: os polos da prática metodológica. Rio de Janeiro: F. Alves, 1977.

BUENO, D. A. Mapeamento de fluxos documentais como elemento de identificação arquivística no âmbito da gestão de documentos. 2013. Dissertação (Mestrado em Ciência da Informação) - Instituto de Arte e Comunicação Social, Universidade Federal Fluminense, Rio de Janeiro, 2013. Disponível em: <http://www.ci.uff.br/ppgci/arquivos/Dissert/2013/DANILO\%20ANDR\%C3\%89\%20B UENO.pdf>. Acesso em: 22 jun. 2015. 
CAMARGO, A. M. A. Arquivo, documento e informação: velhos e novos suportes. Arquivo \& Administração, v. 15-23, n. 1, 1994. Disponível em: $<$ http://www.brapci.ufpr.br/documento.php?dd0=0000003812\&dd1=bde1e >. Acesso em: 22 jun. 2015.

. Sobre espécies e tipos documentais. In: Seminário "Dar Nome aos Documentos: da Teoria à Prática", São Paulo, 2013. Anais eletrônicos... São Paulo: Instituto Fernando Henrique Cardoso, 2015.

; BELLOTTO, H. (Coords.). Dicionário de terminologia arquivística. São Paulo: Associação dos Arquivistas Brasileiros, Núcleo Regional de São Paulo; Secretaria de Estado da Cultura, 1996.

; GOULART, S. Tempo e circunstância: a abordagem contextual dos arquivos pessoais: procedimentos metodológicos adotados na organização dos documentos de Fernando Henrique Cardoso. São Paulo: Instituto Fernando Henrique Cardoso, 2007.

CAPURRO, R. Epistemologia e Ciência da Informação. In: Encontro Nacional de Pesquisa em Ciência da Informação, 5, Belo Horizonte, 2003. Anais... Belo Horizonte: Escola de Ciência da Informação da UFMG, 2003. Disponível em: <http://www.capurro.de/enancib_p.htm>. Acesso em: 07 jul. 2015.

CASSIANI, S. B.; CALIRI, M. H. L.; PELÁ, N. T. R. A teoria fundamentada nos dados como abordagem da pesquisa interpretativa. Rev. Latino-Am. Enfermagem, Ribeirão Preto, v. 4, n. 3, p. 75-88, dez. 1996. Disponível em:

<http://www.scielo.br/pdf/rlae/v4n3/v4n3a07.pdf>. Acesso em: 07 jul. 2015.

CASTELLS, M. A sociedade em rede. A era da informação: economia, sociedade e cultura. São Paulo: Editora Paz e Terra, 1999a. v. I.

CHIAVENATO, I. Gestão de pessoas: o novo papal dos recursos humanos nas organizações. Rio de Janeiro: Campus, 1999b.

CHOO, C. W. A. Organização do conhecimento: como as organizações usam a informação para criar significado, construir conhecimento e tomar decisões. Trad. de Eliana Rocha. 2. ed. São Paulo: Editora Senac São Paulo, 2006. 
CRUZ, C. M. L. Comunicação organizacional e pressupostos da comunicação integrada: a experiência em uma universidade na implementação/reestruturação do jornal institucional. Conexão - Comunicação e Cultura, UCS, Caxias do Sul, v. 6, n. 11, p. 193-209, jan./jun., 2007. Disponível em:

<http://www.ucs.br/etc/revistas/index.php/conexao/article/viewFile/199/190>. Acesso em: 07 jul. 2015.

CRUZ MUNDET, J. R. Manual de archivística. Madri: Fundación Germán Sánchez Ruipérez: Pirámide, 1994.

CUNHA. A. U. N. Mapeamento de processos organizacionais da UnB: caso Centro de Documentação da UnB - CEDOC. 2012. 48 f. Monografia (Especialização em Gestão Universitária) - Departamento de Administração, Faculdade de Economia, Administração e Contabilidade, Universidade de Brasília, UnB. Brasília, 2012. Disponível em:

$<$ http://bdm.unb.br/bitstream/10483/4191/1/2012_AlexUilamardoNascimentoCunha.p df>. Acesso em: 07 jul. 2015.

CURVELLO, J. J. A. Legitimação das assessorias de comunicação nas organizações. In: DUARTE, J. (Org.) Assessoria de imprensa e relacionamento com a mídia: teoria e técnica. 4. ed. São Paulo: Atlas, 2011.

DAVENPORT, T. H. Reengenharia de processos: como inovar na empresa através da Tecnologia da Informação. Rio de Janeiro: Campus, 1994.

DELMAS, B. Manifesto for a contemporary diplomatics: from institutional documents to organic information. American Archivist, v. 59, p. 438-452, 1996. Disponível em: <http://americanarchivist.org/doi/pdf/10.17723/aarc.59.4.kxt762862g115304>. Acesso em: 07 jul. 2015.

DURANTI, L. Diplomática: usos nuevos para una antigua ciencia. Carmona: S\&C. 1996.

. Registros documentais contemporâneos como provas de ação. Estudos Históricos, Rio de Janeiro, v. 7, n. 13, p. 49-64, 1994. Disponível em: <http://bibliotecadigital.fgv.br/ojs/index.php/reh/article/view/1976/2164>. Acesso em: 07 jul. 2015.

; PRESTON, R. International research on permanent authentic records in electronic systems (InterPARES 2): experimential, interactive and dynamic records. Italia: ANAI, 2008. $844 \mathrm{p}$. 
FERAUD, G. Um século de gestão da informaç̧ão. In: MARCHAND, D. A.;

DAVENPORT, T. H. Dominando a gestão da informação. Porto Alegre: Bookman, 2004.

FIGUEIREDO, R.; NASSAR, P. O que é comunicação empresarial. São Paulo: Brasiliense, 1995.

FONSECA, M. O. K. Arquivologia e Ciência da Informação. Rio de Janeiro: Editora FGV, 2005.

FEDERAÇÃO NACIONAL DOS JORNALISTAS - FENAJ. Manual de assessoria de comunicação/imprensa. 4. ed. rev. e ampl. Brasília: FENARJ. 2007. Disponível em: $<$ http://www.fenaj.org.br/mobicom/manual_de_assessoria_de_imprensa4.pdf>. Acesso em: 12 dez. 2015.

FOSKETT, D. J. Informática. In: GOMES, H. E. Ciência da Informação ou informática? Rio de Janeiro: Calunga, 1980.

GONÇALVES, J. E. L. As empresas são grandes coleções de processos. Revista de Administração de Empresas, São Paulo, v. 40, n. 1, p. 6-19, jan./mar, 2000. Disponível em: <http://www.scielo.br/pdf/rae/v40n1/v40n1a02.pdf>. Acesso em: 12 dez. 2015.

JAPIASSÚ, H.; MARCONDES, D. Dicionário básico de Filosofia. 5. ed. Rio de Janeiro: Jorge Zahar Ed., 2008.

KOBASHI, N. Y.; SMIT, J. W.; TÁLAMO, M. F. G. M. A função da terminologia na construção do objeto da Ciência da Informação. DataGramaZero - Revista de Ciência da Informação, v. 2, n. 2, 2001. Disponível em:

$<$ http://bibliodata.ibict.br/geral/docs/funcaodaterminologia.pdf>. Acesso em: $12 \mathrm{dez}$. 2015.

KOPPLIN, E.; FERRARETTO, L. A. Assessoria de imprensa: teoria e prática. 4. ed. Porto Alegre: Sagra Luzzatto, 2001.

KOTLER, P.; ARMSTRONG, G. Princípios de marketing. Rio de Janeiro: LTC Livros Técnicos e Científicos, 1999.

KUNSCH, M. M. K. Planejamento de relações públicas na comunicação integrada. São Paulo: Summus, 1886. 
Relações públicas e modernidade: novos paradigmas na comunicação organizacional. São Paulo: Summus, 1997.

Universidade e comunicação na edificação da sociedade. São Paulo:

$\overline{\text { Loyola, }} 1992$.

LACERDA, A. L. Fotografia como documento de arquivo. In: A fotografia nos arquivos: a produção de documentos fotográficos da Fundação Rockefeller durante o combate à Febre Amarela no Brasil. 2008. Tese (Doutorado) - Faculdade de Filosofia, Letras e Ciências Humanas, Universidade de São Paulo, 2008. Disponível em: <http://www.teses.usp.br/teses/disponiveis/8/8138/tde-11092008-145559/ptbr.php>. Acesso em: 16 jul. 2015.

LAUDON, K. C.; LAUDON, J. P. Sistemas de informação gerenciais. 7. ed. São Paulo: Prentice Hall, 2009.

LE COADIC, Y. A Ciência da Informação. Brasília: Briquet de Lemos, 1996.

LIMA, J. L. O.; ALVARES, L. Organização e representação da informação e do conhecimento. In: ALVARES L. (Org.). Organização da informação e do conhecimento: conceitos, subsídios interdisciplinares e aplicações. 4. ed. São Paulo: B4Editores, 2012. Disponível em:

<http://rbbd.febab.org.br/rbbd/article/view/245/245>. Acesso em: 16 jul. 2015.

LOPES, B. O que é assessoria de imprensa. São Paulo: Brasiliense, 2003.

LOPES, L. C. A gestão da informação: as organizações, os arquivos e a informática aplicada. Rio de Janeiro: Arquivo Público do Estado do Rio de Janeiro, 1997.

A informação e os arquivos: teorias e práticas. Niterói, RJ: EDUFF; São Carlos, SP: EDUFSCar, 1996.

LOPEZ, A. P. A. As razões e os sentidos: finalidades da produção documental e interpretação de conteúdos na organização de documentos imagéticos. 2000. Tese (Doutorado em História Social) - Faculdade de Filosofia, Letras e Ciências Humanas, Universidade de São Paulo, 2000. Disponível em: <http://eprints.rclis.org/12862/1/Andr\%C3\%A9_tese.pdf>. Acesso em: 16 jul. 2015. 
. El contexto archivístico como directriz para la gestión documental de materiales fotográficos de archivo. Universum, Talca, v. 23, n. 2, p. 12-37, 2008. Disponível em: <http://www.scielo.cl/scielo.php?script=sci_arttext\&pid=S0718$23762008000200002>$. Acesso em: 09 jun. 2015.

. Tipologia documental de partidos e associações políticas brasileiras. São Paulo: Loyola, 1999.

LOUSADA, M.; VALENTIM, M. L. P. A relação entre a informação orgânica e a gestão documental. In: VALENTIM, M. L. P. Gestão, mediação e uso da informação. São Paulo: Cultura Acadêmica, 2010.

MARCHIORI, P. Z. A ciência e a gestão da informação: compatibilidades no espaço profissional. Ci. Inf., Brasília, v. 31, n. 2, p. 72-79, maio/ago. 2002. Disponível em: <http://www.scielo.br/pdf/ci/v31n2/12910.pdf/>. Acesso em: 09 jun. 2015.

MARQUES, M. O. Escrever é preciso: o princípio da pesquisa. 5. ed. rev. ljuí, RS: Ed. Unijuí, 2006.

MADIO, T. C. C. Uma discussão de documentos fotográficos em ambiente de arquivo. In: VALENTIM, M. L. P. Estudos avançados em Arquivologia. Marília, SP: Cultura Acadêmica, 2012.

McGARRY, K. J. Da documentação à informação: um contexto em evolução. Lisboa: Editorial Presença, 1984.

MONTEIRO, S. B. S. Análise e melhoria de processos. Brasília, 2014. (Apostila)

PAVEZI, N.; FLORES, D.; PEREZ, C. B. Proposição de um conjunto de metadados para descrição de arquivos fotográficos considerando a Nobrade e a Sepiades. TransInformação, Campinas, v. 21, n. 3, p. 197-205, set./dez., 2009. Disponível em: $<$ http://periodicos.puccampinas.edu.br/seer/index.php/transinfo/article/view/501/481>. Acesso em: 09 jun. 2015.

PINHEIRO, L. V. R. Processo evolutivo e tendências contemporâneas da ciência da informação. Inf. \& Soc.: Est., João Pessoa, v. 15, n. 1, p. 13-48, jan./jun. 2005. Disponível em: <http://www.uff.br/ppgci/editais/processo.pdf>. Acesso em: 09 jun. 2015.

RAMPAZZO, L. Metodologia científica: para alunos dos cursos de graduação e pós-graduação. 2. ed. São Paulo: Loyola, 2004. 
REGO, F. G. T. Comunicação empresarial, comunicação institucional: conceitos estratégias, sistemas, estrutura, planejamento e técnicas. São Paulo: Summus, 1986.

REZENDE, D. S.; LOPEZ, A. P. A. Adecuación de la descripción archivística de documentos fotográficos a los estándares internacionales. In: 2ª Conferencia Anual de Archivos: Archivos e Industrias Culturales, 2014, Girona. Papers. Girona: Ajuntament de Girona, 2014. Disponível em:

<http://www.girona.cat/web/ica2014/ponents/textos/id164.pdf>. Acesso em: 09 jun. 2015.

RIBEIRO, F.; SILVA, A. M. Das ciências documentais à Ciência da Informação: ensaio epistemológico para um novo modelo curricular. 2. ed. Porto: Edições Afrontamento, 2008.

ROBREDO, J. Da ciência de informação revisitada aos sistemas humanos de informação. Brasília: Thesaurus, 2003. v. 1.

ROUSSEAU, J. Y.; COUTURE, C. Os fundamentos da disciplina Arquivística. Lisboa: Publicações Dom Quixote, 1998.

RUDIGER, F. As teorias da cibercultura. 1. ed. Porto Alegre: Sulina, 2011. . Introdução às teorias da cibercultura. Porto Alegre: Sulina, 2004.

SALERNO, M. S. Projetos de organizações integradas e flexíveis: processos, grupos e gestão democrática via espaços de comunicação-negociação. São Paulo: Atlas,2008.

SALVADOR BENÍTEZ, A. De la gestión del patrimonio fotográfico en las instituciones. In: ZALDUA, M. O. (Org.). Del artefacto mágico al píxel: estudios de Fotografía. Madrid: Fadoc. UCM, 2014.

SÁNCHEZ VIGIL, J. M. Documentación fotográfica: visión internacional. In: ZALDUA, M. O. (Org.). Del artefacto mágico al píxel: estudios de Fotografía. Madrid: Fadoc. UCM, 2014.

SANTOS, A. R. Metodologia científica: a construção do conhecimento. Rio de Janeiro: Lamparina, 2007. 
SARACEVIC, T. Ciência da Informação: origem, evolução e relações. Perspectivas em Ciência da Informação, Belo Horizonte, v. 1, n. 1, p. 41-62, jan./jun.1996.

. Interdisciplinarity nature of Information Science. Ciência da Informação, Brasília, v. 24, n. 1, p. 36-41, 1995. Disponível em: $<$ http://www.brapci.ufpr.br/documento.php?dd0=0000005946\&dd1=59269>. Acesso em: 09 jun. 2015.

SCHELLENBERG. T. R. Documentos públicos e privados: arranjo e descrição. Rio de Janeiro: Fundação Getúlio Vargas, 1980.

SILVA, A. K. A.; LIMA I. F.; ARAÚJO, C. A. A. Desvelando a interdisciplinaridade da ciência da informação: o enfoque dos alunos do PPGCI/UFMG. Ci. Inf., Brasília, v. 38, n. 1, p. 31-44, jan./abr. 2009. Disponível em: <http://www.scielo.br/pdf/ci/v38n1/02.pdf>. Acesso em: 20 jul. 2014.

SILVA, A. M. A informação: da compreensão do fenômeno e construção do objecto científico. Porto: Edições Afrontamento, 2006. (Coleção Artes Informação n. 1)

; REAL, M. L.; RIBEIRO, F.; RAMOS, J. S. Arquivística: teoria e pratica de uma Ciência da Informação. Porto: Afrontamento, 1999.

SILVA, E. L. Metodologia da pesquisa e elaboração de dissertação. 4. ed. rev. atual. Florianópolis: UFSC, 2005.

SMIT, J. W.; TÁLAMO, M. F. G. M. Ciência da Informação: uma ciência moderna ou pós-moderna. In: LARA, M. L.; FUJINO, A.; NORONHA, D. P. (Orgs.) Informação e contemporaneidade: perspectivas. Recife: Néctar, 2007.

SOUSA, B. A. Glossário: biblioteconomia, arquivologia, comunicação e ciência da informação. 2. ed. rev. e atual. João Pessoa: Editora Universitária/UFPB, 2008.

SOUSA, R. T. B. A informação orgânica arquivística. In: IV Workshop Internacional em Ciência da Informação, 2009. Disponível em:

<https://arquivoememoria.files.wordpress.com/2009/04/informacaoorganicaarquivisti ca1.pdf>. Acesso em: 04 jul. 2015. 
SUMMERS, R.; OPPENHEIM, C.; MEADOWS, J.; McKNIGHT, C.; KINNELL, M. Information science in 2010: a Loughborough university view. Journal of the American Society for Information Science, v. 50, n. 12, p. 1153-1162, 1999. Disponível em: <http://onlinelibrary.wiley.com/doi/10.1002/(SICI)10974571(1999)50:12\%3C1153::AID-ASI20\%3E3.0.CO;2-H/abstract>. Acesso em: 04 jul. 2015.

TOMANIK, E. A. O olhar no espelho: "conversas" sobre a pesquisa em Ciências Sociais. 2. ed. rev. Maringá, PR: EdUEM, 2004.

TOGNOLI, N. B. A construção teórica da diplomática: em busca da sistematização de seus marcos teóricos como subsídio aos estudos arquivísticos. São Paulo: Cultura Acadêmica, 2014.

UNIVERSIDADE DE BRASÍLIA - UnB. Estatuto e regimento geral. Ed. com emendas e alterações inseridas no Estatuto e no Regimento Geral, aprovadas pelo Conselho Universitário da UnB, por meio da Resolução n. 29/2010, de 7 de dezembro de 2010, publicada no DOU n. 21, de 31/1/2011, p. 124, Seção 1, e da Resolução n. 7/2011, de 24/5/2011, publicado no DOU n. 125 de 1ㅇ/7/2011, p. 11, Seção 1. Brasília, 2011. Disponível em:

<http://www.unb.br/unb/transparencia/downloads/regimento_estatuto_unb.pdf>. Acesso em: 28 set. 2015.

Guia prático de relacionamento com a mídia. Brasília: Editora Universidade de Brasília, 2012.

Secretaria de Comunicação. Missão. Brasília, 2016. Disponível em: <http://www.secom.unb.br/missao.php>. Acesso em: 28 jan. 2016.

UNIVERSIDADE SANTA CRUZ DO SUL - UNISC. Métodos de abordagem e de procedimentos. 2016.

VALENTIM, M. L. P. Gestão documental em ambientes empresariais. In: Estudos avançados em Arquivologia. Marília, SP: Cultura Acadêmica, 2012.

WILSON, T. D. Information management. In: FEATHER, J.; STURGES, P. (Eds.). International Encyclopedia of Information and Library Science. 2. ed. London: Routledge, 2002.

YIN, R. K. Estudo de caso: planejamento e métodos. 2. ed. Porto Alegre: Bookman, 2001. 
ZINS, C. Conceptions of Information Science. Journal of the American Society for Information Science (JASIST), v. 58, n. 3, p. 335-350, 2007. Disponível em:

<http://onlinelibrary. wiley.com/doi/10.1002/asi.20507/abstract;jsessionid=DE9AEB44 3B94D0841B69690447F479FA.d04t02>. Acesso em: 28 set. 2015. 
APÊNDICE 


\section{APÊNDICE "A" - RESUMO DA ENTREVISTA COM O FOTÓGRAFO DA SECRETARIA DE COMUNICAÇÃO DA UNIVERSIDADE DE BRASÍLIA}

Entrevista realizada em 11 de dezembro de 2015, nas dependências da Secretaria de Comunicação da Universidade de Brasília (SECOM/UnB).

Tânia Moura: Quantas pessoas trabalham na Seção de Fotografias da SECOM?

Júlio Minasi: Duas pessoas, por enquanto, o fotógrafo oficial, que sou eu, e uma estagiária de fotografia, aluna do curso de jornalismo, que trabalha quatro horas no horário vespertino.

Tânia Moura: Além dessas duas pessoas, o resto da equipe da SECOM atua na Seção de Fotografias?

Júlio Minasi: Na parte de fotografia, não.

Tânia Moura: Como são feitas as fotos?

Júlio Minasi: Nós utilizamos equipamento digital, fazemos a captura das fotos nos locais de evento e trazemos para a sala da SECOM, onde fazemos o tratamento das imagens e o arquivamento. As etapas são: descarregar o cartão de memória da máquina fotográfica no computador e designar um HD (Hard Disk $\left.{ }^{13}\right)$ externo - entre os quatro que temos, para o armazenamento das fotos. A partir daí fazemos o tratamento e a pré-seleção das imagens. Esse tratamento seria da parte estética da imagem, de contraste, exposição...às vezes é necessário fazer isso. Depois de feito o tratamento estético, colocamos num HD no formato nativo, que o RAW ${ }^{14}$. Esse HD externo comporta muitas fotos. Depois disponibilizamos em formato JPG num outro HD chamado "Secomx" que está conectado à rede interna compartilhada. Os outros jornalistas têm acesso às fotos que eu coloco lá.

Tânia Moura: Como é tomada a decisão de fazer as fotografias?

Júlio Minasi: Eu, particularmente, sigo um protocolo feito por mim mesmo. Dependendo da cerimônia sigo um padrão de fotografia (inaugurações, professor emérito, reuniões, uma obra ou uma pessoa que foi destacada). A decisão sobre o tipo (técnica) de fotografia é minha. Às vezes ocorre de conversar anteriormente

13 Significa "Disco Rígido". É a memória permanente do computador e armazena todas as informações que são salvas pelo usuário, além de aplicações próprias do sistema operativo. O HD é também chamado de "memória secundária". Cf. Significados. 2016. Disponível em: $<$ http://www.significados.com.br/hd/>. Acesso em: 30 jan. 2016.

$14 \mathrm{Um}$ sistema binário de armazenamento que existe em certas câmeras digitais que atestam que a fotografia está "sem processamento", "sem tratamento" ou "cru" [...]. Este formato mantém a integridade da imagem, pois impede que qualquer manipulação seja salva no mesmo arquivo, sendo necessária, para salvar as alterações realizadas, a conversão para outro formato como o TIFF ou JPG. Em termos gerais, raw é o negativo digital "cru". É importante saber que cada fabricante gera um arquivo raw com características diferentes, e por isso, o arquivo só abre em determinados softwares, fazendo com que o software de um fabricante não abra o arquivo de outro. Cf. ARAÚJO, J. C. B. A. Fotografia digital como prova no processo - Aspectos tecnológicos. Âmbito Jurídico, Rio Grande, a. XIII, n. 83, dez. 2010. Disponível em: <http://www.doraci.com.br/downloads/fotografo/Integridade-da-imagem-digital.pdf>. Acesso em: 29 jan. 2016. Cf. ARAÚJO, A. P. Formato raw. In: Infoescola, 2016. Disponível em: <http://www.infoescola.com/fotografia/formato-raw/>. Acesso em: 29 jan. 2016. 
com o repórter que está fazendo a pauta, nós trabalhamos juntos. Daí ele indica quem são as pessoas que devem sair na foto, mas é raro, pois, na maioria das vezes, a gente já sabe qual é a liturgia que tem que fazer ali. A decisão de sair para fazer a fotografia é enviada por e-mail, pelo Editor, com o cronograma da semana de pautas. Esse cronograma tem a data, a hora, qual jornalista vai trabalhar comigo e o local. Nisso, é disponibilizado um carro ou, se for perto, vamos a pé mesmo. E daí sabemos dia e hora que teremos uma pauta para cobrir. Já está agendado. Pode acontecer, às vezes, um pedido que não estava em pauta, como o caso em que o Reitor pediu que fizéssemos umas fotos de uma delegação que ele recebeu. Ele pediu que fizesse como registro que, inclusive, não foi utilizado em nenhum periódico aqui. Eu mandei as fotos para as pessoas da delegação que queriam as fotos. Então, sigo uma pauta prevista e, eventualmente, demandas específicas da Reitoria. As pautas são gerais dentro da universidade.

Tânia Moura: Recebida a demanda da pauta, quais são as próximas etapas?

Júlio Minasi: Então, vamos ao local, fazemos as fotos sabendo que nos periódicos da UnB serão usadas, no máximo, três fotos. Costumo tirar uma quantidade de fotos maior para formar um banco de dados, principalmente de pessoas, autoridades e professores. Até porque somos muito consultados, são pedidas muitas fotos, por agências, jornais (Correio Brasiliense, Correio do Espírito Santo, por exemplo), todos os jornais do Brasil e vários países até. As pessoas vêm aqui pedindo fotografias de professores, de cerimônias...são os próprios professores, familiares e tal. Nós costumamos disponibilizar. São feitas, mais ou menos, entre 80 a 200 fotos, usamos em média 03 e ficamos com o banco de dados.

Tânia Moura: Como é feita a identificação das fotografias?

Júlio Minasi: Trazemos o equipamento, descarregamos o arquivo das fotos no HD específica que é chamado Seagate - que tem 2 Tb de capacidade. Colocamos a data, o nome do assunto e o nome do fotógrafo para termos um parâmetro do dia, mês e ano. Usamos a data como referência e as chamadas palavras-chaves para recuperar as fotos. Nesse programa que utilizamos, o Lightroom $^{15}$ que faz toda a parte de edição de fotos e pré-arquivamento, é bem completo. É uma biblioteca. Por meio dele posso fazer uma pesquisa ou ir direto nos HD's.

Tânia Moura: Ele está sendo utilizado há quanto tempo?

Júlio Minasi: Ele está sendo usado há quatro ou cinco anos, por aí. Eu já conhecia esse sistema e já usava como fluxo de trabalho. No setor de biblioteca ele tem vários assuntos, divididos pelos diversos HDs que podemos escolher, os específicos.

Tânia Moura: E quando completa um HD, o que fazem?

Júlio Minasi: Quando completa um HD's fazemos um trabalho periódico de limpeza. Eu mesmo fiz uma revisão agora, quando cheguei, de fotos que não tinham potencial para serem editadas, colocadas em sistema. O pessoal anterior, os estagiários, tirou muita foto que não tinha qualidade para publicação. Então, como já foram selecionadas as fotos usadas, eu eliminei algumas e deixei algumas que

${ }^{15}$ Adobe Photoshop Lightroom é um aplicativo para Windows, iOS, Android e Mac OS, que auxilia no gerenciamento e na edição de imagens, focando a maioria dos seus recursos na manipulação de fotografias. Cf. CARVALHO, R. Use o Adobe Photoshop Lightroom para editar suas fotos. In:

Techtudo, 20 de fevereiro de 2015. Disponível em: <http://www.techtudo.com.br/tudosobre/adobe-photoshop-lightroom.html>. Acesso em: 1ํ fev. 2016. 
pudessem ter serventia para nós, como fotos de professores, de eventos, uma honra ao mérito, alguma homenagem, isso aí é bem importante pra gente guardar.

Tânia Moura: Você disse que identifica as pessoas pelo nome, mas tem como saber quem são essas pessoas?

Júlio Minasi: Na maioria das vezes identificamos, até pela pauta. Por exemplo, numa honra ao mérito de professor já colocamos o nome dele. Às vezes, quando alguma determinada área está recebendo um prémio, existe um professor responsável, aí colocamos o nome dele, até como uma maneira de depois recuperar, fazer uma pesquisa no arquivo. Neste caso aqui, foi feita uma reportagem, uma pauta, sobre uma pesquisadora que está fazendo um trabalho de análise da agua do Rio Doce, aqui na UnB, no Campi de Planaltina ${ }^{16}$. Eu fui com o repórter, ele fez a pauta, eu fiz as imagens. Aí quando eu trouxe pra nossa estação de trabalho, eu já especifiquei o assunto, como está aqui: "análises toxicológicas em amostras da agua do Rio Doce", 03 de dezembro de 2015, Júlio Minasi - fotógrafo.

Tânia Moura: E sobre os HD's, como você gerencia?

Júlio Minasi: Os quatro HD's que tenho aqui estão interligados e só um está compartilhado no "Secomx", ele tem vinte e dois Gb livres, mas já esteve extremamente lotado, eu comecei a fazer a limpeza. Aqui trabalha toda parte de assessoria de imprensa, design, fotografia, pauta, relações institucionais e relatórios, numa estrutura de diretórios. Tem ainda o UnB Hoje e o nosso técnico de TI (Tecnologia da Informação) é o Amilton Augusto. Então, todas essas pastas que estão compartilhadas se falam entre si. Cada área da SECOM tem uma pasta e tem uma área de trabalho. Todos aqui dentro têm acesso a essas pastas, que seriam como as seções internas da SECOM. Aqui temos os arquivos da parte de fotografias é essa de 2014 a 2015. Elas são pré-divididas em meses. Aqui é a área que eu aboli, estou terminando de organizar. O que acontecia? O pessoal que trabalhava anteriormente fazia as fotos, trazia e salvava na pasta compartilhada todas as fotos em raw, um arquivo muito pesado, mas que só abre no programa que te mostrei (Lightroon) e só a Seção de Fotografia tem. Então, se vou disponibilizar uma fotografia, sou obrigado a converter para um formato que alguém possa abrir lá em seu computador, por exemplo JPG. Como antes estavam disponibilizando na pasta compartilhadas esses arquivos crus, estavam consumindo muito espaço desnecessariamente, sem utilização diária. Eles compartilhavam com todos, coisas que nem todos utilizariam. O que comecei a fazer? Pedi um HD novo, que veio do CPD (Centro de Informática), que tem mais de dois TB. Estou utilizando como um depósito, um banco de dados de fotografias raw 2015 e disponibilizo pro pessoal em arquivo JPG, que abre em qualquer computador e é um arquivo que não ocupa muito espaço. Assim, eles não precisam da minha presença para escolher as fotografias, pois eu seleciono e converto as que considero melhores para publicação. Disponibilizo umas dez ou quinze pelos setores em JPG, para os setores, os jornalistas, e eles mesmos escolhem as que vão usar. Eu já deixo préselecionadas as que, por exemplo, vão para o Flickr $^{17}$ ou Facebook. Assim, eles não precisam ficar dependentes de mim.

Tânia Moura: Teria a possibilidade de eles usarem a mesma foto para publicações diferentes?

\footnotetext{
${ }^{16}$ Faculdade UnB Planaltina (FUP).

${ }^{17}$ O Flickr é um aplicativo online de hospedagem, gerenciamento e compartilhamento de imagens fotográficas e vídeos, caracterizado também como rede social.
} 
Júlio Minasi: Não, no dia não, pois eles fazem consciente ainda. Porém, se eles precisam de uma foto de anos atrás que foi publicada em outro periódico, já aconteceu deles precisarem dela e usarem a mesma de novo. Essas aqui são as do "cotidiano", são fotos que costumamos ilustrar nosso Flickr e Facebook. O Flickr não tem muita visualização, mas o Facebook tem bastante. Tem também o portal da Universidade, em que colocamos alguma coisa, é uma área que deixa o pessoal da Fotografia mais à vontade.

Tânia Moura: Eu percebi que no portal da Universidade, as fotos do Flickr estão identificadas com o mesmo nome. Quer dizer, tem várias fotos com a mesma identificação.

Júlio Minasi: Conseguimos agora, há pouco tempo, entrar no Flickr, ele estava desativado, porque a estagiária anterior saiu e não nos deixou a senha, a senha não batia. Tivemos que fazer contato de novo e solicitar uma nova senha e agora a estagiária que trabalha conosco tem atualizado as fotos no Flickr diariamente. Fazemos as fotos para ilustrar o portal e também para disponibilizar, caso alguém queira alguma imagem.

Tânia Moura: Como é feita a escolha das fotografias depois que você as disponibiliza?

Júlio Minasi: Quando cheguei aqui eu perguntava para as pessoas: você quer escolher a foto junto comigo? Que foto tu 'quer'? Eu personalizava a escolha, mas isso criou uma demanda enorme para mim. Então eu pensei: tenho que confiar no meu olhar, para ter uma coisa mais independente. Passei então a fazer as fotos e compartilhar. Se, por acaso, alguém não gostar aí escolhemos outra. Porque senão gera uma dependência, perde-se muito tempo, engessa o trabalho.

Temos um outro sistema o Administrador Master, de inserção dos textos jornalísticos, em que colocamos as fotografias. É o responsável por colocar no site. Utilizamos esse sistema para inserir as fotografias. Funciona assim: o repórter faz o texto e eu incluo a fotografia. Todo dia eu acesso o sistema, verifico se tem alguma reportagem que está faltando fotografia. Escolho a (s) foto (s) que eu queria, faço a inserção e visualizo. É automático. Depois o Editor publica a matéria no portal da UnB.

Tânia Moura: Quais são os profissionais envolvidos na produção das fotografias?

Júlio Minasi: O fotógrafo, o jornalista/repórter e o Editor.

Tânia Moura: Como vocês lidam com as questões de direito autoral das fotografias?

Júlio Minasi: A questão da utilização de fotografia é bem delicada. Se forem feitas por órgãos públicos (federais, agências) nós podemos pegar para usar, assim como eles podem pegar as nossas. Mas, quando é feita por fotógrafo particular nós não costumamos utilizar, porque ele quer uma remuneração por aquela foto. Claro, até porque tem a questão do direito autoral da foto. Seria muito fácil entrar na internet ou no Google e buscar uma foto que eu quero, só que aquela foto alguém tirou. E para não gerar algum problema maior, utilizamos o que está disponibilizado para nós. Quando eu quero uma foto dessas eu entro no site oficial do governo e pego, eventualmente, entro em contado - mando e-mail ou faço contato telefônico. Mas, na maioria das vezes, por ser de órgão público, vamos lá e pegamos. Claro fazendo todas as referências. O crédito sempre tem que dar, até por uma questão ética. Como no meu caso, eu, pessoa, estou fotografando para a UnB, tenho o crédito da 
imagem, mas não tenho o direito autoral sobre a fotografia. A foto foi feita por mim, mas estou a serviço da Universidade. Em outras situações conversamos com as pessoas retratadas e solicitamos autorização. 